See discussions, stats, and author profiles for this publication at: https://www.researchgate.net/publication/296682906

\title{
Dinoflagellate cyst production over an annual cycle in seasonally ice-covered Hudson Bay
}

Article in Marine Micropaleontology · March 2016

DOI: 10.1016/j.marmicro.2016.02.005

CITATIONS

28

6 authors, including:

Maija Heikkilä

University of Helsinki

33 PUBLICATIONS 961 CITATIONS

SEE PROFILE

Alexandre Forest

Laval University

58 PUBLICATIONS 1,140 CITATIONS

SEE PROFILE
READS

570

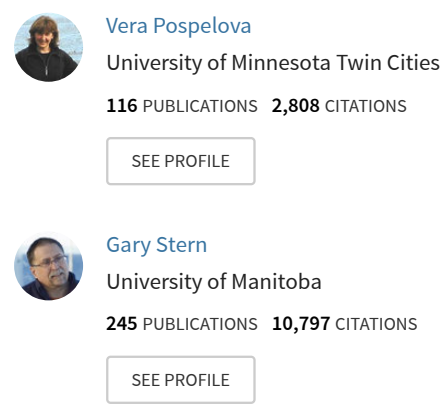

Some of the authors of this publication are also working on these related projects:

MALINA View project

Neurotoxicological risk of mercury exposure for beluga whales from the Mackenzie Delta Estuary View project 
Research paper

\title{
Dinoflagellate cyst production over an annual cycle in seasonally ice-covered Hudson Bay
}

\author{
Maija Heikkilä a,b,*, Vera Pospelova ${ }^{\mathrm{c}}$, Alexandre Forest ${ }^{\mathrm{d}}$, Gary A. Stern ${ }^{\mathrm{b}}$, Louis Fortier ${ }^{\mathrm{d}}$, Robie W. Macdonald ${ }^{\mathrm{b}, \mathrm{e}}$ \\ a Environmental Change Research Unit, Department of Environmental Sciences, P.O. Box 65, 00014 University of Helsinki, Finland \\ b Centre for Earth Observation Science, University of Manitoba, 496 Wallace Building. Winnipeg MB R3T 2N2, Canada \\ c School of Earth and Ocean Sciences, University of Victoria, OEASB A405, P.O. Box 1700 STN CSC, Victoria BC V8W 2Y2, Canada \\ d Université Laval, Takuvik Joint Laboratory, Pavillon Alexandre-Vachon 1045, Avenue de la Médecine Local VCH-2064, Quebec City, QC G1V 0A6, Canada \\ e Institute of Ocean Sciences, Department of Fisheries and Oceans, 9860 W. Saanich Road, P.O. Box 6000, Sidney, BC V8L 4B2, Canada
}

\section{A R T I C L E I N F O}

\section{Article history:}

Received 11 June 2015

Received in revised form 17 February 2016

Accepted 27 February 2016

Available online 2 March 2016

\section{Keywords:}

Dinoflagellate cyst

Sea-ice

Hudson Bay

Arctic

Sediment trap

Phytoplankton dynamics

Tintinnid loricae

Ciliate

\begin{abstract}
A B S T R A C T
We present continuous bi-weekly to bi-monthly dinoflagellate cyst, tintinnid loricae and tintinnid cyst fluxes at two mooring sites in Hudson Bay (subarctic Canada) from October 2005 to September 2006. The total dinoflagellate cyst fluxes at the site on the western side of the bay ranged from 4600 to $53,600 \mathrm{cysts} \mathrm{m}^{-2}$ day $^{-1}$ (average 20,000 cysts $^{-2}$ day $^{-1}$ ), while on average three times higher fluxes (average 62,300 cysts $^{-2}$ day $^{-1}$ ) were recorded at the site on the eastern side of the bay with a range from 2700 to 394,800 cysts m $^{-2}$ day $^{-1}$. These values are equivalent to the average fluxes calculated from the top $1-\mathrm{cm}$ sediment layer of $210 \mathrm{~Pb}$-dated box cores at corresponding locations, and hence lend support to the use of sediment dinoflagellate cysts in palaeoceanography. Tintinnid fluxes ranged from 1200 to 80,000 specimens $\mathrm{m}^{-2}$ day $^{-1}$ (average 32,100 tintinnids $\mathrm{m}^{-2}$ day $^{-1}$ ) in the west, and 1600 to $1,240,800$ specimens $\mathrm{m}^{-2}$ day $^{-1}$ (average 106,800 tintinnids $\mathrm{m}^{-2} \mathrm{day}^{-1}$ ) in the east, with the highest Salpingella sp. fluxes recorded during the sea-ice cover season.

The dinoflagellate cyst species diversity recorded in the traps was similar at the two environmentally differing locations, with cold-water (e.g., Echinidinium karaense, Islandinium minutum, Islandinium? cezare, Polykrikos sp. var. arctica, Spiniferites elongatus), cosmopolitan (e.g., Operculodinium centrocarpum, Spiniferites ramosus, Brigantedinium) and typical warmer-water (e.g., Echinidinium aculeatum, Islanidium brevispinosum) species present. Furthermore, the species-specific timing of cyst production behaved similarly relative to the seasonal sea-ice cycle at both locations. Cyst species proportions and species-specific flux quantities, however, differed between the two sites and corresponded to the quantities and species assemblages recorded in the surface sediment, with the exception of cysts of Polarella glacialis and cf. Biecheleria sp. that seem not to preserve well in sediment but were abundant in both traps. Otherwise, cyst assemblage at the western trap site was dominated by 0 . centrocarpum and S. elongatus while at the eastern site very high quantities of cysts of Pentapharsodinium dalei were recorded. Our data do not lend support to the hypothesis that trophic status solely determines whether cyst production takes place under-ice or in the open water, since cysts of light-dependent (phototrophic) and light-independent (heterotrophic) dinoflagellates are recorded during both conditions. Most importantly, negligible under-ice cyst production is recorded during the deep arctic winter.
\end{abstract}

(c) 2016 Elsevier B.V. All rights reserved.

\section{Introduction}

Marine phytoplankton and their immediate grazers are excellent tracers of environmental conditions that encumber or enable their growth and reproduction, notably, local and seasonal variability in light availability, nutrient status, temperature, and water-column stability (Margalef, 1978; Falkowski and Oliver, 2007; Cloern and Jassby, 2008; Marinov et al., 2010). Plankton assemblages consist of a large

\footnotetext{
* Corresponding author at: Environmental Change Research Unit, Department of Environmental Sciences, P.O. Box 65, 00014, University of Helsinki, Finland.

E-mail address: maija.heikkila@helsinki.fi (M. Heikkilä).
}

number of species that exhibit highly species-specific responses to environmental forcing, engendering unique records of multivariate community response to environmental change. Moreover, the turnover rates of phytoplankton biomass are in the order of a week (e.g., Falkowski et al., 1998), enabling virtually immediate reactions to changing habitat conditions in comparison to the response rates of years to centuries for terrestrial higher plants (Walther et al., 2002).

Past phytoplankton communities, and hence, sea-surface conditions in the ocean can be studied using sedimentary remains of common phytoplankton organisms: mainly siliceous frustules of diatoms, organic-walled resting cysts of dinoflagellates, and calcareous plates of coccolithophores. Owing to inherent mixing within the sediment 


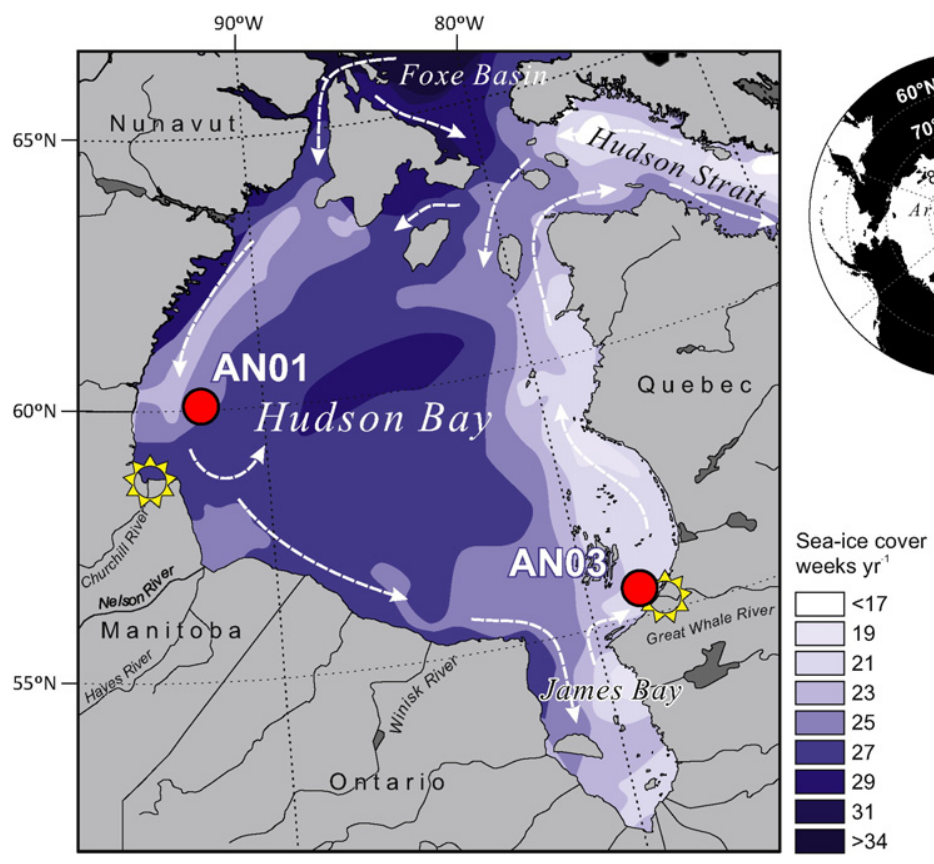

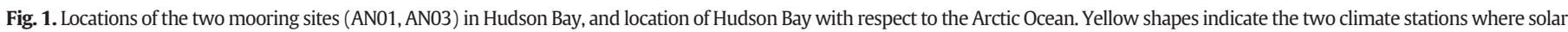

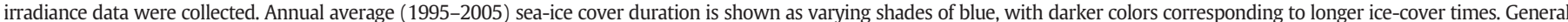
surface water circulation is indicated with dashed arrows. (For interpretation of the references to colour in this figure legend, the reader is referred to the web version of this article.)

surface layer and generally low marine sediment accumulation rates, the record of phytoplankton dynamics in the upper water column is usually averaged to a temporal resolution from years (coastal sites) to millennia (deep ocean). As a consequence, sedimentary cores or surface samples are not suitable for studying seasonal patterns in the absence of information on seasonal production windows, but they may record long-term changes (decadal or greater) in phytoplankton dynamics including production and dominant species. In certain cases, high quality modern plankton monitoring data, e.g., Continuous Plankton Recorder (Warner and Hays, 1994), may be used to assess the seasonal significance of the species encountered in the sedimentary record. Extensive, long-term biological monitoring data at the species-level are rare, however, and phytoplankton surveys are particularly sparse in remote polar and sub-polar marine regions (Archambault et al., 2010; Wassmann et al., in press; Bluhm et al., 2011). Automated particle-intercepting sediment traps deployed at a depth of interest collect settling particulate matter throughout the year at a selected temporal interval, typically weekly to monthly, and provide crucial information of seasonal plankton dynamics, especially when costly and labor-intensive seagoing monitoring is not feasible year-round. Sediment traps may be retrieved one or more times per year, and the time-slices of settled organic matter analyzed for species composition.

Dinoflagellates comprise autotrophic (light-dependent), heterotrophic (light-independent) and mixotrophic (capable of both photosynthesis and ingestion of prey) microplankton organisms (Taylor, 1987; Jeong et al., 2010). Here we use the term phototrophic for dinoflagellates that are capable of photosynthesis. Life histories of a number of dinoflagellate species alternate between motile planktonic and resting stages, the latter is termed cyst (e.g., Dale, 1983; Pfiester and Anderson, 1987; Head, 1996). Production of resting cysts (encystment) is generally indicative of the pelagic bloom (Heiskanen, 1993; Ishikawa and Taniguchi, 1996; Garcés et al., 2004), and in dominantly seasonal marine systems encystment is often an annually recurring event that creates an inoculum for future motile populations. Benthic resting cysts differ from corresponding planktonic dinoflagellates both morphologically and structurally. Motile dinoflagellates are commonly surrounded by cellulosic walls or armour (i.e. theca), whereas most resting cysts are protected by resistant, cell walls composed of carbohydrate-based, structurally variable dinosporin (e.g. Versteegh et al., 2012; Bogus et al., 2014), enabling excellent preservation in contrast to siliceous and calcareous remains of diatoms and coccolithophores that are subject to dissolution (see however, Zonneveld et al., 1997, 2010b). Consequently, sediment-column dinoflagellate cyst assemblages provide an attractive archive of decadal- to millennial-scale variability in sea-surface conditions (e.g., de Vernal et al., 1997; Rochon et al., 1998; Ellegaard, 2000; Harland et al., 2006; Pospelova et al., 2006; Bouimetarhan et al., 2009; Bonnet et al., 2010; Pieńkowski et al., 2011; Price et al., 2013; Bringué et al., 2014). The striking sea-ice loss in the Arctic seas ( $-4 \%$ per decade of annual average extent and $-14 \%$ per decade during September sea-ice minimum)(Serreze et al., 2007; Cavalieri and Parkinson, 2012; Stroeve et al., 2012), has a multitude of repercussions, invoking an acute need to understand the natural long-term dynamics of arctic climate and ecosystems beyond the era of satellite observations. Proxy data provide a key element in assessing the resilience of modern-day sea-ice ecosystems to perturbations and defining their pre-anthropogenic variability. Hence, the development and assessment of climate and sea-ice reconstructions in the Arctic is timely and critically needed.

One of the key challenges in the application of sediment dinoflagellate cysts as tracers of past environments, particularly in polar and subpolar seas, is the limited knowledge of the life-cycle transitions of individual dinoflagellate species (Rochon, 2009; Kremp, 2013): i.e., the seasonal patterns and environmental cues of cyst production and the relationships of sedimentary cysts to their planktonic counterparts are not known. This challenge is not always faced outright since spatial distribution of dinoflagellate cysts in recently deposited surface sediments can be directly linked to modern average surface water conditions via statistical modeling, i.e., "transfer functions", without the need to consider planktonic motile stages or the transitions in the life cycle. Transfer functions derived from modern data numerically define relations between modern cyst species and environmental variables (Guiot and de Vernal, 2007) and can be applied to sediment-core cyst assemblages to estimate quantitatively past sea-surface conditions, e.g., salinity, temperature, and sea-ice duration (de Vernal et al., 2001, 2005). The transfer function approach can produce high-grade estimates of past environmental variability, but scrutiny and ecological insight are required in the selection of meaningful variable(s) to reconstruct 
(Juggins, 2013), and in the design of modern calibration sets (Telford and Birks, 2011). Clearly, the development of transfer functions and the interpretation of qualitative and quantitative reconstructions based on sediment-core assemblages would greatly benefit from the knowledge of the biology and ecology of dinoflagellate life cycle transitions.
There is a handful of studies that portray seasonal sediment trap series of dinoflagellate cyst fluxes, quintessentially located in low- and mid-latitude settings: central (Dale, 1992), southern (Prebble et al., 2013), northwestern (Fujii and Matsuoka, 2006; Shin et al., 2012) and northeastern Pacific (Pospelova et al., 2010; Price and Pospelova, 2011; Bringué et al., 2013), southeastern Atlantic (Susek et al., 2005;

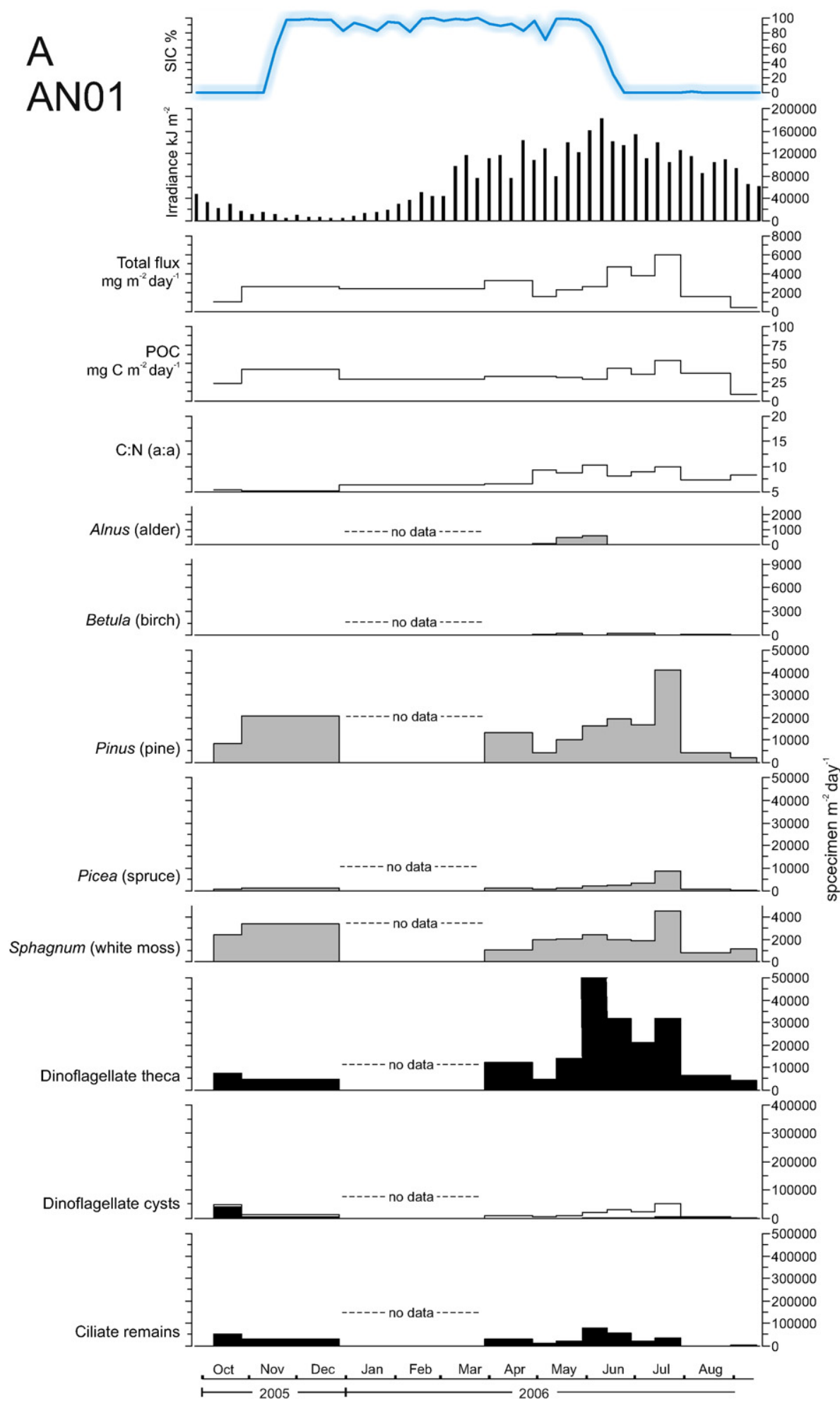

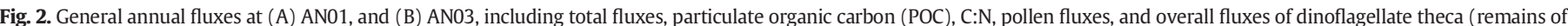

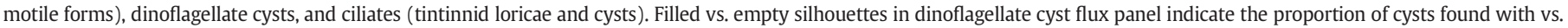

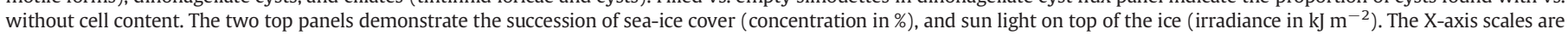
comparable for AN01 (A) and AN03 (B). 
Table 1

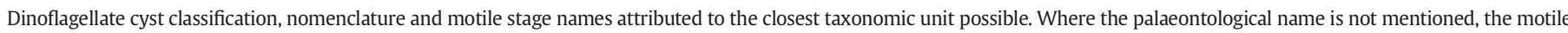
stage name is used for the resting cyst stage. 1SAR is a supergroup containing Stramenopiles, Alveolates and Rhizaria (Burki et al., 2007; Adl et al., 2012).

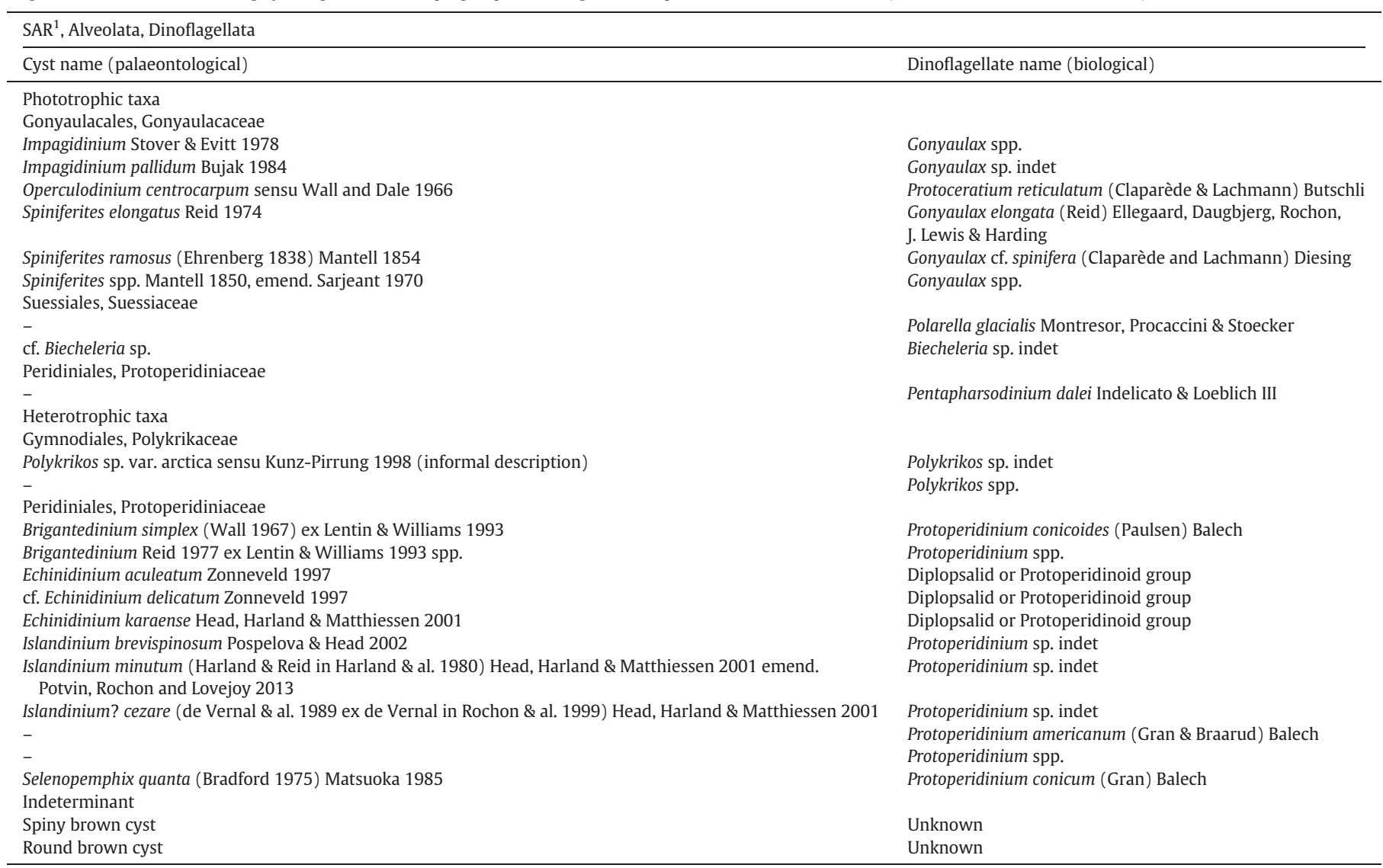

Pitcher and Joyce, 2009; Zonneveld et al., 2010a), western Indian Ocean (Zonneveld and Brummer, 2000), and Mediterranean Sea (Montresor et al., 1998). As far as we know, there are two studies that probe fluxes of dinoflagellate cysts underneath sea ice (Harland and Pudsey, 1999; Howe et al., 2010). Harland and Pudsey (1999) placed six sediment traps for 1-2 years in the nepheloid layer of Bellingshausen, Weddell

Table 2

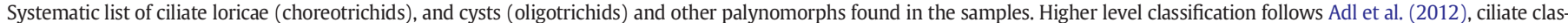

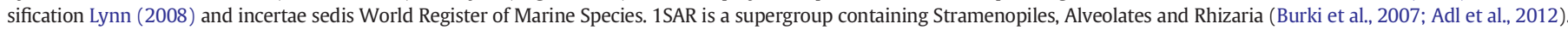

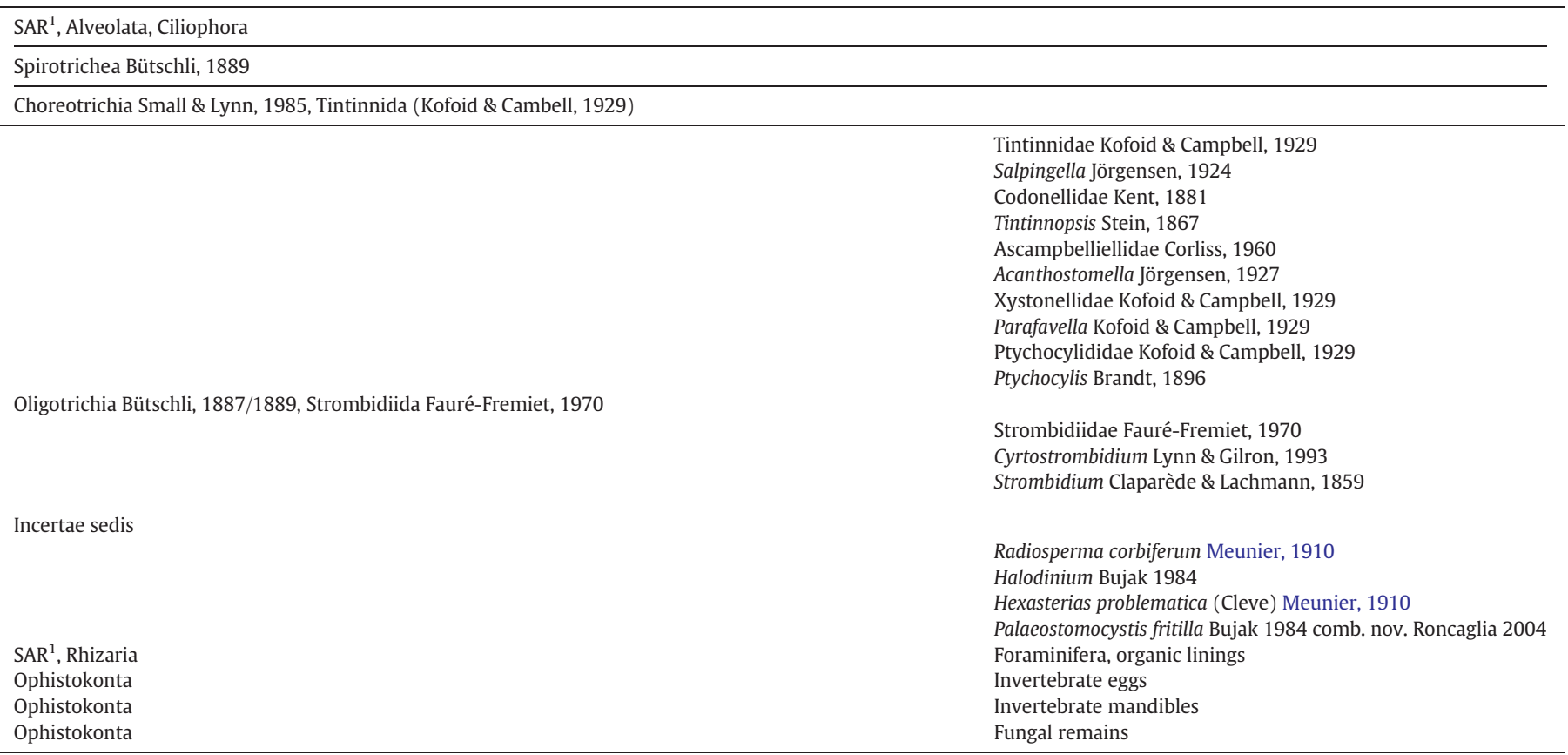



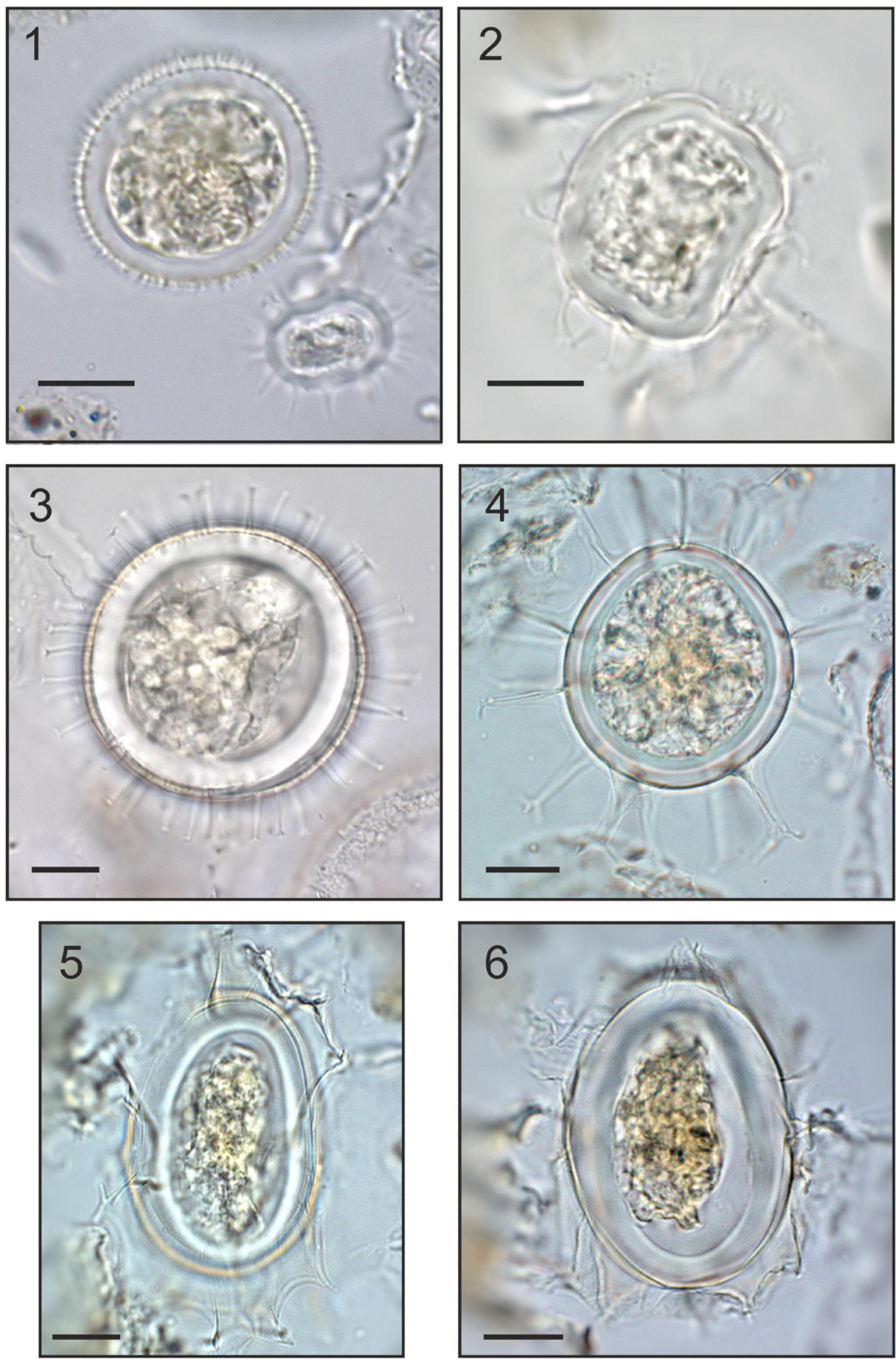

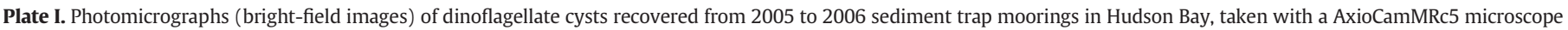

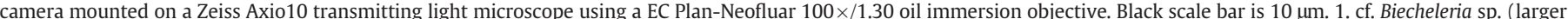

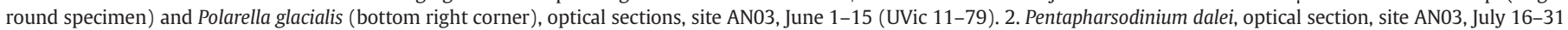

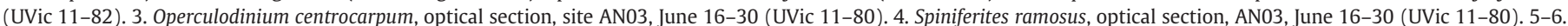
Spiniferites elongatus s.l., optical sections, site AN01, October 14-31 (UVic 11-61). 
and Scotia Seas (Antarctic), and calculated daily cyst fluxes based on the total accumulation over the deployment. They found the highest cyst accumulation outside the sea-ice zone, and dominance of heterotrophic species at all locations, with differing species compositions in relation to sea-ice margin. As the authors note, these data provide average values over the annual or biennial deployment, giving no information about seasonal patterns of cyst production. Howe et al. (2010), on the other hand, analyzed some time slices from a ca. 14-month deployment period in two fjords from Svalbard archipelago, with two samples presenting fluxes under the sea-ice cover and during its breakup. No cysts were recovered from the trap when the sea surface was ice-covered. Interestingly, however, autotroph Pentapharsodinium dalei had its peak flux in the summer in the fjord that was ice-covered in the winter, while heterotrophs Islandinium minutum and Selenopemphix quanta dominated the samples from the other fjord that remained open throughout the year. Globally available surface sediment data demonstrate that the cysts of I. minutum and certain other heterotrophic species, particularly Islandinium? cezare, the arctic morphotype of the genus Polykrikos (Polykrikos sp. var. arctica), Echinidinium karaense, and Selenopemphix antarctica (endemic to circum-Antarctic), dominate in marine regions where seasonal ice-cover times are close to a year (Rochon et al., 1999; Mudie and Rochon, 2001; Matthiessen et al., 2005; de Vernal et al., 2013; Zonneveld et al., 2013), and thus their dominance over certain sediment-core intervals has been interpreted as a time period with prolonged seasonal sea-ice cover. It has been assumed that heterotrophic dinoflagellates perhaps dominate over autotrophs in seasonally ice-covered systems because they do not photosynthesize and are better able to cope with reduced periods of light availability. While the above-mentioned "sea-ice indicators" are common in polar seas, it is generally unknown whether the motile life stages producing these cyst types actually thrive in the dark within- or under-ice environments, and whether their encystment occurs inside or under the sea-ice pack, or during the open-water season.

We studied bi-weekly to bi-monthly cyst fluxes using two automated sediment traps deployed close to the seafloor throughout one year (October 2005-September 2006) in western and eastern Hudson Bay, Canadian Subarctic, to document and explain in situ temporal encystment patterns of northern cold-water dinoflagellates. We compare the total annual fluxes and species composition from the traps to the fluxes calculated from modern surface sediments of these two environmentally and biologically distinct locations of the bay (Heikkilä et al., 2014). We then decipher how the seasonal production of different cyst species is linked to sea-ice regime and light availability, and discuss the implications for application of dinoflagellate cyst species for environmental reconstruction.

\section{Materials and methods}

\subsection{Study region}

Hudson Bay is a seasonally ice-covered inland sea located in the transition zone of boreal and Arctic Canada. It experiences an annual cycle from fully ice-covered in winter (December-May) to fully icefree in summer (July-October) (Fig. 1). In western Hudson Bay, where our study site AN01 is located, seasonal sea-ice cover lasts about 4-8 weeks longer than in the eastern part of the Bay, where the study site AN03 lies. The significant freshwater input from ice melt and river discharge in spring is contained in a counter-clockwise circulation gyre along the perimeter of the Bay (Prinsenberg, 1986a, 1986b). On account of the circulation pattern and the substantial input from rivers draining into James Bay, freshwater accumulates in the southeastern and eastern parts of the corridor (Granskog et al., 2011). Hence, even though both of our study sites lie within the freshwater-dominated coastal zone, salinities are higher and summer surface mixed layer depth lower in the west than in the east (Anderson and Roff, 1980; Prinsenberg, 1984; Ferland et al., 2011; Lapoussière et al., 2013). Furthermore, during the open-water season the southeastern region around trap site AN03 is often the warmest region in Hudson Bay (see Suppelementary Table 1)(Galbraith and Larouche, 2011).

Hudson Bay is an oligotrophic system with an estimated annual new primary production of 10-70 $\mathrm{g} \mathrm{C} \mathrm{m}^{-2} \mathrm{yr}^{-1}$ (Roff and Legendre, 1986; Sakshaug, 2004; Ferland et al., 2011; Lapoussière et al., 2009). Surface water nutrient availability is limited by strong summertime stratification (Ingram and Prinsenberg, 1998), and the bulk of phytoplankton biomass and marine organic carbon production are concentrated at the polynyas, near-shore and northern regions where coastal currents and upwelling feed the nutrient pool (Kuzyk et al., 2010; Ferland et al., 2011).

Terrigenous organic matter (OM) provides an important contribution to the vertical particle flux in the coastal regions of Hudson Bay, particularly in the east and southeast (Kuzyk et al., 2009, 2010). Furthermore, lateral transport and recycling of sediments play a noteworthy role, manifesting themselves as increasingly oxidized sedimentary OM towards the interior of the Bay (Kuzyk et al., 2011; Hare et al., 2014). The spatial patterns in the quality of sedimentary OM within the Bay indicate that the trap at site AN01 likely records a more marine signature than the trap at site AN03; yet the supply of highly degraded, laterally transported organic sediment is more likely at the former location.

Diatoms are the dominating component in the summer and fall phytoplankton assemblages at the mouth of the Hudson Bay and in Hudson Strait (>80\%), while flagellates and dinoflagellates typically represent half of the assemblage and the majority of phytoplankton carbon biomass in Hudson Bay proper (Harvey et al., 1997; Lapoussière et al., 2009; Ferland et al., 2011). Little is known of the phytoplankton composition in spring and winter due to inaccessibility to research vessels, and hence the few studies in the region have concentrated on the near-shore environments, primarily in southeastern Hudson Bay (Michel et al., 1993; Legendre et al., 1996). Average cyst fluxes calculated from surface sediment in the southeast (close to AN03) are over three times higher than in the west (close to AN01), primarily owing to the dominance of the prolific cyst producer $P$. dalei along the eastern shore (Heikkilä et al., 2014). Furthermore, cyst species assemblages on the two sides of the Bay differ distinctly: in the east, P. dalei and Spiniferites ramosus are the most common autotrophic species, while Operculodinium centrocarpum and Spiniferites elongatus are typical in the west. Heterotrophs, particularly Polykrikos sp. var. arctica, are generally more numerous in the west.

\subsection{Mooring}

Two Technicap PPS 3/3 sediment traps ( 12 cups; $0.125 \mathrm{~m}^{2}$ aperture) were deployed and recovered during ArcticNet annual expeditions on board of the Canadian Coast Guard Ship Amundsen in 2005 and the Canadian Coast Guard Ship Pierre Radisson in 2006, respectively (Lalande and Fortier, 2011). Station AN01 (59 $58^{\prime} \mathrm{N}$; 91 ${ }^{\circ} 56^{\prime} \mathrm{W}$; water depth $=$ $107 \mathrm{~m}$ ) was established in western Hudson Bay and station AN03 $\left(55^{\circ} 24^{\prime} \mathrm{N} ; 77^{\circ} 55^{\prime} \mathrm{W}\right.$; water depth $\left.=136 \mathrm{~m}\right)$ near the mouth of the Great Whale River in southeastern Hudson Bay (Fig. 1). Traps were deployed 20-30 m above the seabed: AN01 at $81 \mathrm{~m}$ and AN03 at $100 \mathrm{~m}$ depth. The trap sample cups were filled with filtered seawater (Whatman GF/F, nominal pore size of $0.7 \mu \mathrm{m}$ ), poisoned with formalin ( $5 \% \mathrm{v} / \mathrm{v}$ ), buffered with sodium borate, and adjusted to a salinity of 35 with $\mathrm{NaCl}$ to preserve samples during deployment and after recovery.

\subsection{Light availability}

Available light energy was assessed as total solar irradiance $\left(\mathrm{kJ} \mathrm{m}^{-2}\right)$ at climate stations in Churchill $\left(58.75^{\circ} \mathrm{N}, 94.07^{\circ} \mathrm{W}, 29.3 \mathrm{~m}\right.$ a.s.l) and Kuujjuarapik $\left(55.28^{\circ} \mathrm{N}, 77.77^{\circ} \mathrm{W}, 10.4 \mathrm{~m}\right.$ a.s.l), corresponding to AN01 and AN03, respectively (Fig. 1). Weekly totals were calculated from modeled hourly global horizontal irradiance amounts derived from Canadian Weather Energy and Engineering Datasets (CWEEDS, 1953- 

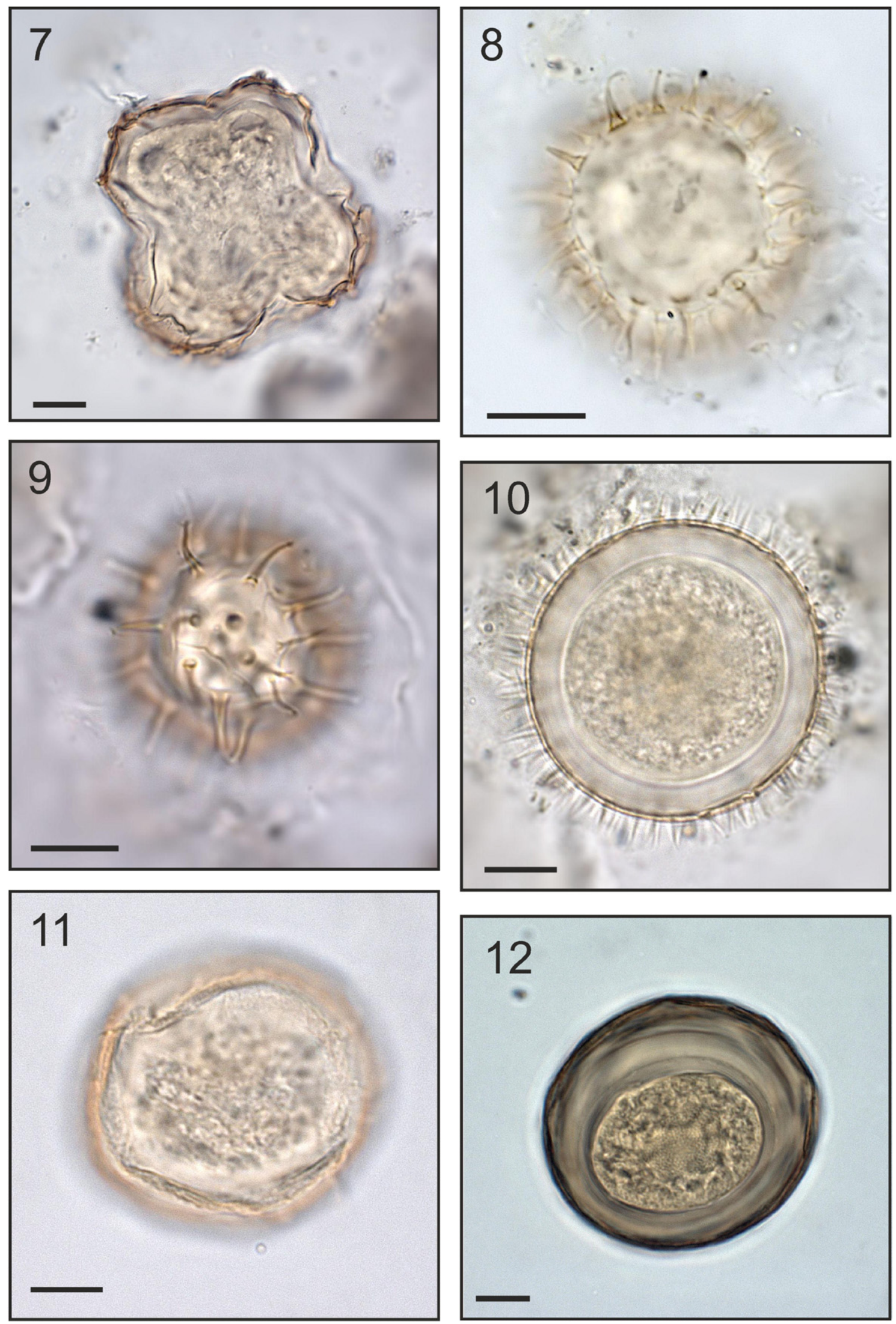

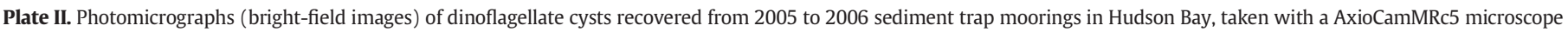

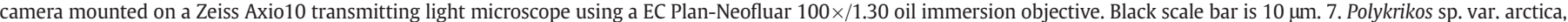

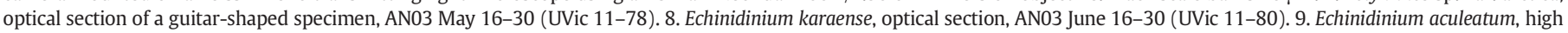

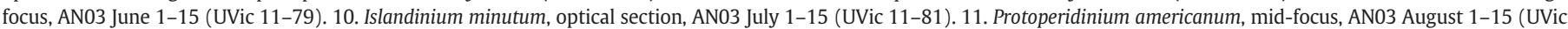
11-83). 12. Brigantedinium sp., optical section, AN03 June 1-15 (UVic 11-79). 
2005), extended by the National Climate Services Canada to the end of year 2006 at the stations concerning this study.

Sea-ice concentrations (\%) were derived from remotely-sensed passive microwave sea-ice products of the National Snow and Ice Data Center (NSIDC) (Meier et al., 2013) and are reported as weekly averages for a $0.2^{\circ} \times 0.2^{\circ}$ area above the mooring.

\subsection{Mass, carbon and nitrogen measurements}

Triplicate split samples were filtered with combusted $\left(4 \mathrm{~h}\right.$ at $450{ }^{\circ} \mathrm{C}$ ) GF/F filters, rinsed with distilled water to remove salt, dried for $12 \mathrm{~h}$ at $60{ }^{\circ} \mathrm{C}$ and weighed. The filters were exposed to concentrated $\mathrm{HCl}$ fumes for $12 \mathrm{~h}$ to remove carbonates and dried again at $60{ }^{\circ} \mathrm{C}$. Particulate organic carbon (POC) and particulate nitrogen (PN) were analyzed via Perkin Elmer CHNS 2400 Series II elemental analyzer. Mass $\left(\mathrm{mg} \mathrm{m}^{-2} \mathrm{~d}^{-2}\right.$ ) and POC fluxes ( $\mathrm{mg} \mathrm{C} \mathrm{m}^{-2} \mathrm{~d}^{-2}$ ) were averaged for each collection period and should be considered as minimal estimates as they were not corrected for solubilization of organic material.

\subsection{Palynomorph extraction and nomenclature}

Known proportions of each sediment trap sample were processed in the Paleoenvironmental/Marine Palynology Laboratory at the University of Victoria, Canada, for dinoflagellate cysts according to the preparation protocol by Pospelova et al. (2005). Other organic-walled microfossils, such as pollen grains and spores, zooplankton remains (foraminifer linings, copepod eggs, ciliate loricae and cysts, invertebrate mandibles), as well as remains of dinoflagellate theca were recovered at the same time. Samples were rinsed with deionized water three times to remove salt residue and oven dried at $40{ }^{\circ} \mathrm{C}$. Lycopodium clavatum marker grains were added to each sample in order to estimate cyst fluxes (Stockmarr, 1972; Mertens et al., 2009, 2012). Samples were treated with $10 \% \mathrm{HCl}$ to digest carbonates, sieved with nylon mesh to retain material between 15 and $120 \mu \mathrm{m}$, soaked 2-4 days in $48 \%$ HF to remove silicates, and treated again with $10 \% \mathrm{HCl}$ to remove precipitated fluorosilicates. All chemical digestions were made in room temperature acids. Samples were then rinsed, gently sonicated for up to $30 \mathrm{~s}$ and collected on a 15$\mu \mathrm{m}$ nickel mesh. Microscope slides were prepared by mounting ca. $1 \mathrm{ml}$ of homogenized residue in warmed glycerine jelly. Dinoflagellate cysts, pollen, spores and other organic-walled microfossils were identified to species level where possible, using a Zeiss Standard 20 transmitting light microscope with $600 \times$ and $1000 \times$ magnifications. On average 410 (min. 102) dinoflagellate cysts and 1387 (min. 340) palynomorphs (total of dinoflagellate cysts, pollen, spores, ciliate loricae and cysts and organic-walled microfossils) were counted per sample.

Higher level taxonomy follows the most recent classification of eukaryotes by Adl et al. (2012), where SAR supergroup containing the groups Stramenopila, Alveolata (including dinoflagellates and ciliates), and Rhizaria was formalized. Dinoflagellate cyst taxonomy follows the palaeontological system according to Fensome et al. (1993), Lentin and Williams (1993), Head et al. (2001), Zonneveld (1997), Pospelova and Head (2002) and Rochon et al. (1999) (Table 1). Tintinnid loricae and ciliate cysts were identified based on Meunier (1910), Bérard-Therriault et al. (1999) and materials derived from World Register of Marine Species (Warren, 2013) and their classification follows Lynn (2008) (Table 2). Some dinoflagellate cyst taxa were grouped for the multivariate statistical analysis. The genus Brigantedinium comprises Brigantedinium simplex and all unspecified Brigantedinium (due to invisible archaeopyle). 0 . centrocarpum consists of O. centrocarpum sensu Wall and Dale (1966) that has fully developed processes and other 0 . centrocarpum specimens with short or poorly developed processes ("Type B" or "Arctic morphotype" sensu de Vernal et al. (1989) and Radi et al. (2001)). Undifferentiated Spiniferites includes all specimens of the genus except $S$. ramosus and S. elongatus. Most of Polykrikos specimens in Hudson Bay were assigned to Polykrikos sp. var. arctica (see also Heikkilä et al., 2014) according to informal descriptions from the Laptev Sea by Kunz-
Pirrung (1998) and in the northern North Atlantic, Arctic and Sub-Arctic dinoflagellate cyst database by de Vernal et al. (2001).

Polarella glacialis and its cysts have been described from sea-ice brine channels in Arctic and Antarctic (Stoecker et al., 1997; Montresor et al., 1999, 2003). However, cyst wall of P. glacialis likely is not composed of a structurally resistant type of dinosporin (Montresor et al., 1999), and the long-term preservation in sediment or resistance to chemical sample preparation are unknown. This species is generally not reported in palaeoceanographic studies, but it has been recovered and recorded in surface sediments of Hudson Bay (Heikkilä et al., 2014).

Specimens of cf. Biecheleria sp. resemble cysts of Biecheleria baltica described from the brackish northern Baltic Sea (Kremp et al., 2005; Moestrup et al., 2009). This taxon has a body diameter ranging from 8 to $22 \mu \mathrm{m}$ and it is usually observed with cell content. Numerous and evenly distributed processes range from 0.5 and $3 \mu \mathrm{m}$. Similar specimens were found in the surface sediments of Hudson Bay (Heikkilä et al., 2014), and have been identified from northeastern Pacific Ocean (Pospelova et al., 2010; Price and Pospelova, 2011; Bringué et al., 2013).

\subsection{Multivariate statistical analysis}

Constrained ordination was used to summarize species-specific encystment in response to light availability (sea-ice cover and solar irradiance). After data exploration with multiple ordination options, only the data for cysts with cell content were used in an attempt to minimize the influence of resuspended cysts on the analysis. Cyst species data were entered as $\log$-transformed fluxes $\left[\log \left(\right.\right.$ specimen $\left.\left.\mathrm{cm}^{-2} \mathrm{a}^{-1}\right)\right]$, to treat log-normal distributions, respectively. First, detrended correspondence analysis (DCA) was performed to decipher the shape of cyst fluxes along the main environmental gradients (Hill and Gauch, 1980). Redundancy analysis (RDA) was selected for constrained ordination, since gradient (DCA Axis 1) lengths 1.8 s.d. for flux data point to mostly linear species responses. Partial RDAs were also run to partition the variance explained by sea ice and irradiance, and their joint contribution (Borcard et al., 1992). Significance of the canonical models was tested with Monte Carlo permutation, and the adjusted coefficients of determination $\left(R^{2}\right.$ adj $)$ were calculated according to Peres-Neto et al. (2006) using the formula $R_{\text {adj }}^{2}=1-\left(\left(1-R^{2}\right) \times(n-1)\right) /(n-m-1)$, where $n$ is the number of objects (samples) and $m$ is the number of explanatory variables. Traditional $R^{2}$ is biased for sample and predictor size, and adjusted values have been corrected for the degrees of freedom in the model. Because $R^{2}$ adj and adjusted fractions of variation are unbiased estimates, they are generally much lower than unadjusted counterparts (Borcard et al., 2011). In order to assess the predictive power of our model with two predictors (sea ice and irradiance), unconstrained ordination ( principal components analysis, PCA) was run on the data. The premise was that since unconstrained ordination attempts to find the underlying gradients in the data (without measured environmental predictors), the first PCA axis represents the best possible environmental variable that theoretically could be found to explain the data structure.

\subsection{Comparison with surface sediment data}

Dinoflagellate cyst fluxes and assemblages at the two trap sites including cysts with and without cell content were compared with those of the corresponding surface sediment samples (sites 6 and 12 in Heikkilä et al., 2014). Annual total flux data for the traps were calculated over the deployment period and amended with average fluxes for the missing part of the year (ca. 1 month); assemblage data were calculated as average proportions. Annual fluxes for the surface sediment sites were calculated from the top 1-cm samples based on sediment velocities and accumulation rates (Kuzyk et al., 2009); compositional data were raw percentages (Heikkilä et al., 2014). Two dissimilarity measures were used: the chord distance that is more sensitive to cyst assemblage composition ("quality" of the sample) and the Euclidean 

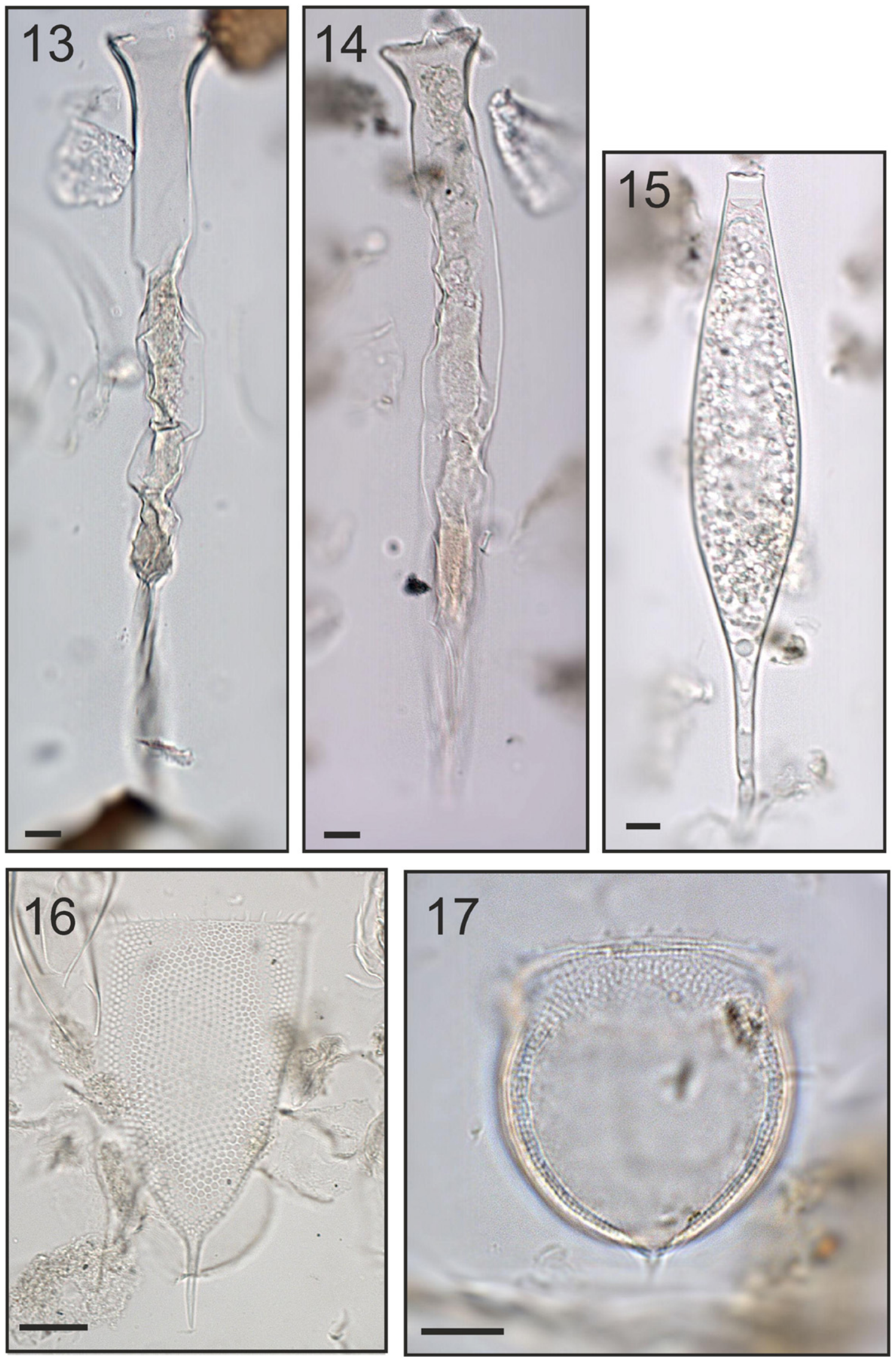

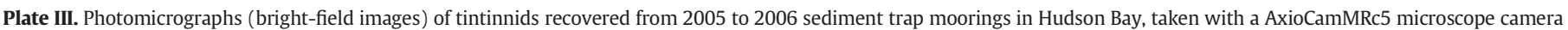

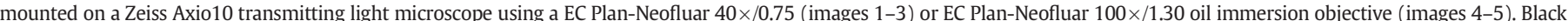

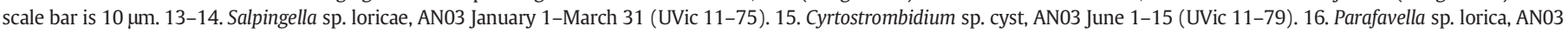
June 16-30 (UVic 11-80). 17. Acanthostomella sp. lorica, AN01 (UVic 11-67). 
distance that uses untransformed data and hence reflects the scale of the descriptor (here fluxes and percentages). Euclidean distance mirrors the dominant cyst taxa and totals ("quantity" of the sample).

\section{Results}

\subsection{Seasonal cycle of light availability}

Consolidated sea ice (sea-ice concentration (SIC) $>80 \%$ ) covered the western trap site (AN01) for approximately seven months from midNovember to mid-June (top panel of Figs. $2 \mathrm{~A}, 3 \mathrm{~A}$ and $4 \mathrm{~A}$ ). At the eastern site (AN03), freeze-up began about one month later (mid-December) and breakup about one month earlier (mid-May), and duration of seaice cover was about five months (top panel of Figs. 2B, 3B and 4B). At both sites the freeze-up was completed in a week, whereas the breakup from consolidated ice to open water took about 1-2 weeks. Solar irradiance at Kuujjuarrapik and Churchill stations increased in April, when the trap sites were still ice-covered, and exhibited maxima in May-June (second panel in Figs. 2, 3 and 4).

\subsection{Mass, carbon and general fluxes}

Seasonal variation in total mass and POC fluxes, C:N (a:a) ratios, and general fluxes of pollen, dinoflagellate theca, cysts and ciliates are presented in Fig. 2 together with SIC and irradiance. Mass and POC fluxes at AN01 were highest (4-6 $\mathrm{g} \mathrm{m}^{-2} \mathrm{day}^{-1}$ and $45-55 \mathrm{mg} \mathrm{m}^{-2} \mathrm{day}^{-1}$, respectively) after the ice breakup in July, but there was a continuous flux of material to the trap throughout the year (Fig. 2A). C:N ratios vary between 5 and 7 in fall and winter and 7-10 during the breakup and in early summer. At AN03, mass and POC fluxes in spring and summer were lower than at AN01 (1.5-2.5 $\mathrm{g} \mathrm{m}^{-2} \mathrm{day}^{-1}$ and $20-30 \mathrm{mg} \mathrm{m}^{-2} \mathrm{day}^{-1}$ ), but C:N ratios were higher (7-18), particularly in under-ice spring samples (13-18, Fig. 2B). Before the freeze-up in November-December a massive particle flux of $38 \mathrm{~g} \mathrm{~m}^{-2}$ day $^{-1}$ ( $85 \mathrm{mg} \mathrm{POC} \mathrm{m}^{-2} \mathrm{day}^{-1}$ ) was deposited in the trap, characterized by an elevated C:N ratio (17.6).

Pollen fluxes, particularly at AN03, present a standard phenological spring sequence starting with alder (Alnus), followed by birch (Betula) and conifers (Pinus and Picea), but significant quantities of pollen of these trees and spores of Sphagnum mosses were also deposited in November-December outside the flowering season. At AN03 this took place concurrently with the anomalously high mass and POC fluxes. Total fluxes of dinoflagellate theca were highest during the openwater season, while copious amounts of theca also settled into the trap underneath spring pack ice. Total dinoflagellate cyst and ciliate fluxes exhibited distinct peaks in the open-water season in JuneNovember, often simultaneously for both groups.

\subsection{Dinoflagellate cyst fluxes}

Average dinoflagellate cyst flux was ca. 20,000 cysts $\mathrm{m}^{-2}$ day $^{-1}$ at site AN01 $\left(\min 4600 \mathrm{~m}^{-2} \mathrm{day}^{-1}, \max 53,600 \mathrm{~m}^{-2} \mathrm{day}^{-1}\right.$ ), and

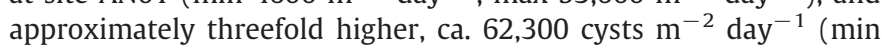
$2700 \mathrm{~m}^{-2}$ day $^{-1}$, max $394,800 \mathrm{~m}^{-2}$ day $^{-1}$ ), at site AN03, respectively (Fig. 2, second lowest panel). Overall, dinoflagellate cyst fluxes at the two sites (Fig. 3) portray species-specific patterns of seasonal cyst production, particularly at AN03 (Fig. 3B). At AN01, the majority of the cysts of heterotrophs were found without cell content throughout the year (Fig. 3A). Cysts of ice-dwelling autotroph P. glacialis were deposited in a pulsed manner after the ice breakup, concurrently with cysts of cf. Biecheleria sp. Cyst fluxes of other autotrophic dinoflagellates (P. dalei, O. centrocarpum, S. ramosus, S. elongatus) peaked in October at AN01, and in the end of July and November-December at AN03. Heterotrophic dinoflagellate cysts found during and immediately after the ice breakup were Polykrikos sp. var. arctica, E. karaense, Echinidinium aculeatum, Islandinium brevispinosum and I.? cezare, whereas summertime open- water cyst producers were I. minutum, Brigantedinium, cf. Echinidinium delicatum and Protoperidinium americanum. During the dark winter months cyst fluxes were negligible; no data are available for JanuaryMarch at site AN01. (See Plates I-II for photomicrographs of typical cyst specimen).

\subsection{Dinoflagellate theca and other palynomorph fluxes}

Fig. 4 presents fluxes of other microscopic remains of organic-walled organisms: dinoflagellate theca (armours of motile stage), ciliate loricae and cysts, copepod eggs, foraminifer linings, invertebrate mandibles, and arcitarchs ("of unknown origin") Halodinium, Hexasterias problematica, and Radiosperma corbiferum. Average fluxes of tintinnid loricae and cysts are higher than those of dinoflagellate cysts at both sites: from 1200 to 80,000 specimens $\mathrm{m}^{-2}$ day ${ }^{-1}$ (average 32,100 tintinnids $\mathrm{m}^{-2} \mathrm{day}^{-1}$ ) at AN01, and from 1600 to $1,240,800$ specimens $\mathrm{m}^{-2}$ day $^{-1}$ (average 106,800 tintinnids $\mathrm{m}^{-2-}$ day $^{-1}$ ) at AN03. (Fig. 2, lowest panel). Again, fluxes of these specimens show clear spring and summer sequences at AN03, but patterns at AN01 are somewhat equivocal. Notably, at both sites Protoperidinium theca were deposited in copious amounts under the ice cover in April-May. At AN03, cysts of ciliates Strombidium and Cyrtostrombidium were deposited during and after ice breakup, whereas other ciliate remains were found in high quantities at the end of July and in November-December concurrently with phototrophic dinoflagellate cysts. These include arctic-boreal genera Parafavella and Ptychocylis. Loricae of Salpingella were the only specimens found exclusively during the winter months. At AN01, clear peaked patterns are not as obvious, although most dinoflagellate theca and ciliate remains types exhibited highest fluxes during the ice breakup. Remains of zooplankton and other predators were generally found at the same time with high dinoflagellate cyst and ciliate fluxes. (See Plates III for photomicrographs of ciliate remains).

\subsection{Relation of cyst species to light availability}

Constrained ordination, here RDA, extracts structures in the species data set that are related to predictor variables. Hence, when interpreting the biplot in Fig. 5, one has to keep in mind that our analysis seeks to explain the distribution of the samples and species in relation to sea ice and irradiance, but does not state that those two are the sole factors influencing cyst production.

The two canonical RDA axes explain $20.3 \%$ of variation in cyst flux data or $11.9 \%$ when accounted for bias (Fig. 5, Table 3). The variation partitioning with unbiased proportions shows that irradiation explains slightly larger part of the variation than sea ice (Fig. 6, Table 3), and only $1.6 \%$ of the total variation is explained by their shared effects. A similar conclusion can be drawn from low variation inflation factors in RDA and the low correlation coefficients of SIC and irradiation (diagnostics not shown). The proportion of unexplained variation is notable (88.1\%), but not uncharacteristically large for ecological data. A PCA run with the same samples found that the first axis explained $38.4 \%$ of total variation in flux data, illustrating the proportion explained by a theoretical environmental variable with highest possible explanatory power. This value can be compared with the variation explained by the RDA model with sea ice and irradiance (20.3\%, adjusted estimate $11.9 \%)$, showing that the PCA has about three-fold higher explanatory power than RDA model with bias-corrected axes.

The RDA biplot (Fig. 5) demonstrates that, in general, the cyst fluxes are either negatively related to or not related to sea ice concentration. Roughly similar patterns were derived when cysts without cell content were included in the analysis, and when the sites were treated separately. Additionally, fluxes of some cyst species (Polykrikos sp. var. arctica, $P$. glacialis, E. karaense) increase with higher irradiance, whereas cyst fluxes of other species (S. ramosus, S. elongatus, P. americanum, P. dalei, O. centrocarpum) are higher with lower irradiances. 


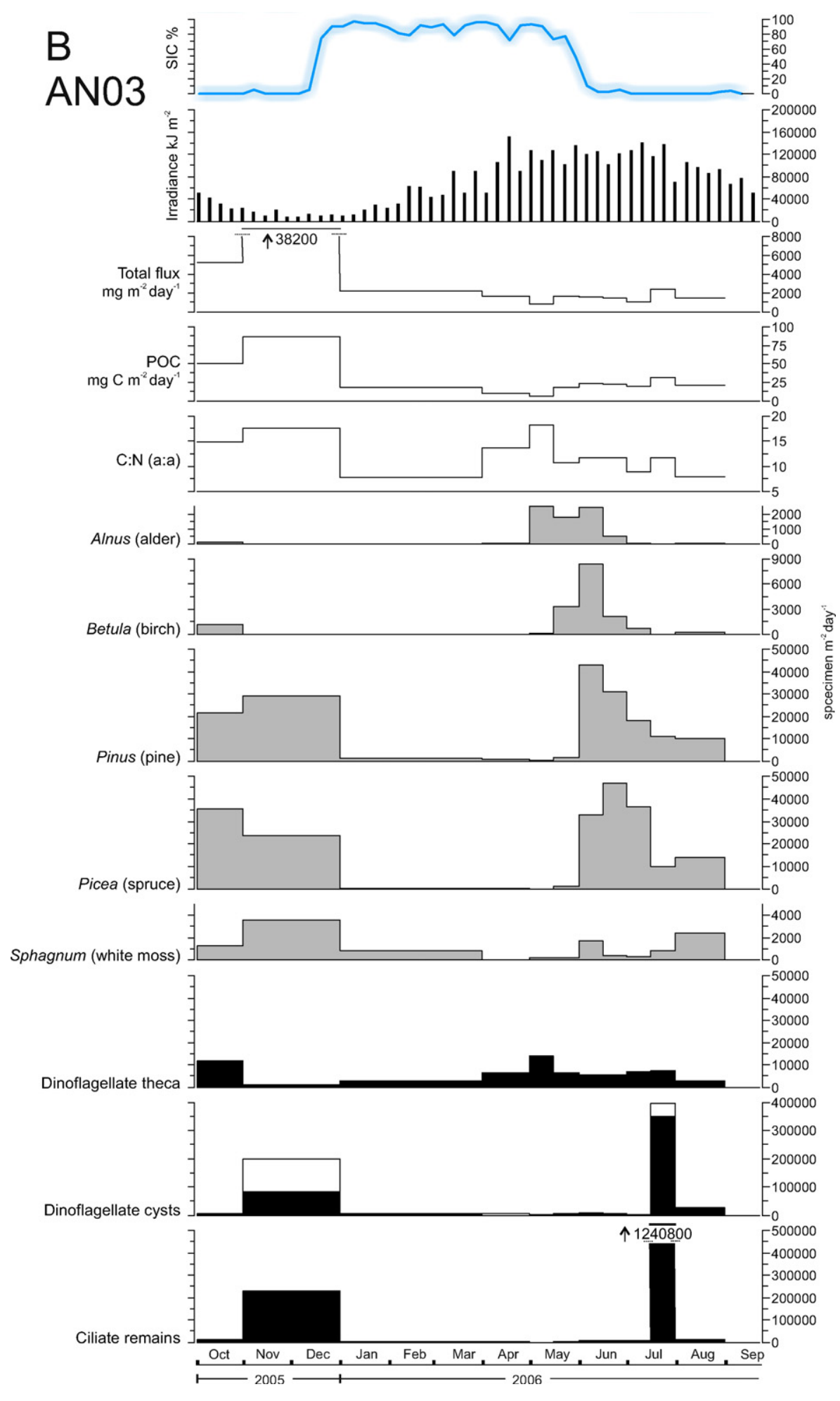

Fig. 2 (continued).

\subsection{Comparison with surface sediment data}

Dinoflagellate cyst fluxes from October 2005 to September 2006 at the two trap-mooring sites are concordant with average fluxes and composition at corresponding surface sediment sites, with threefold dinoflagellate cyst fluxes recorded in the eastern location compared to the western location when assessed by trap data and the surface sediment layer of $210 \mathrm{~Pb}$-dated box-cores. Furthermore, the estimated average fluxes based on the trap data and the surface sediment data are very close to each other: 62,300 cysts $\mathrm{m}^{-2}$ day $^{-1}$ vs. 65,700 cysts $^{-2}$ day $^{-1}$ for the eastern sites and 20,000 cysts $^{-2}$ day $^{-1}$ vs. 20,500 cysts $\mathrm{m}^{-2}$ day $^{-1}$ for the western sites. Some differences 


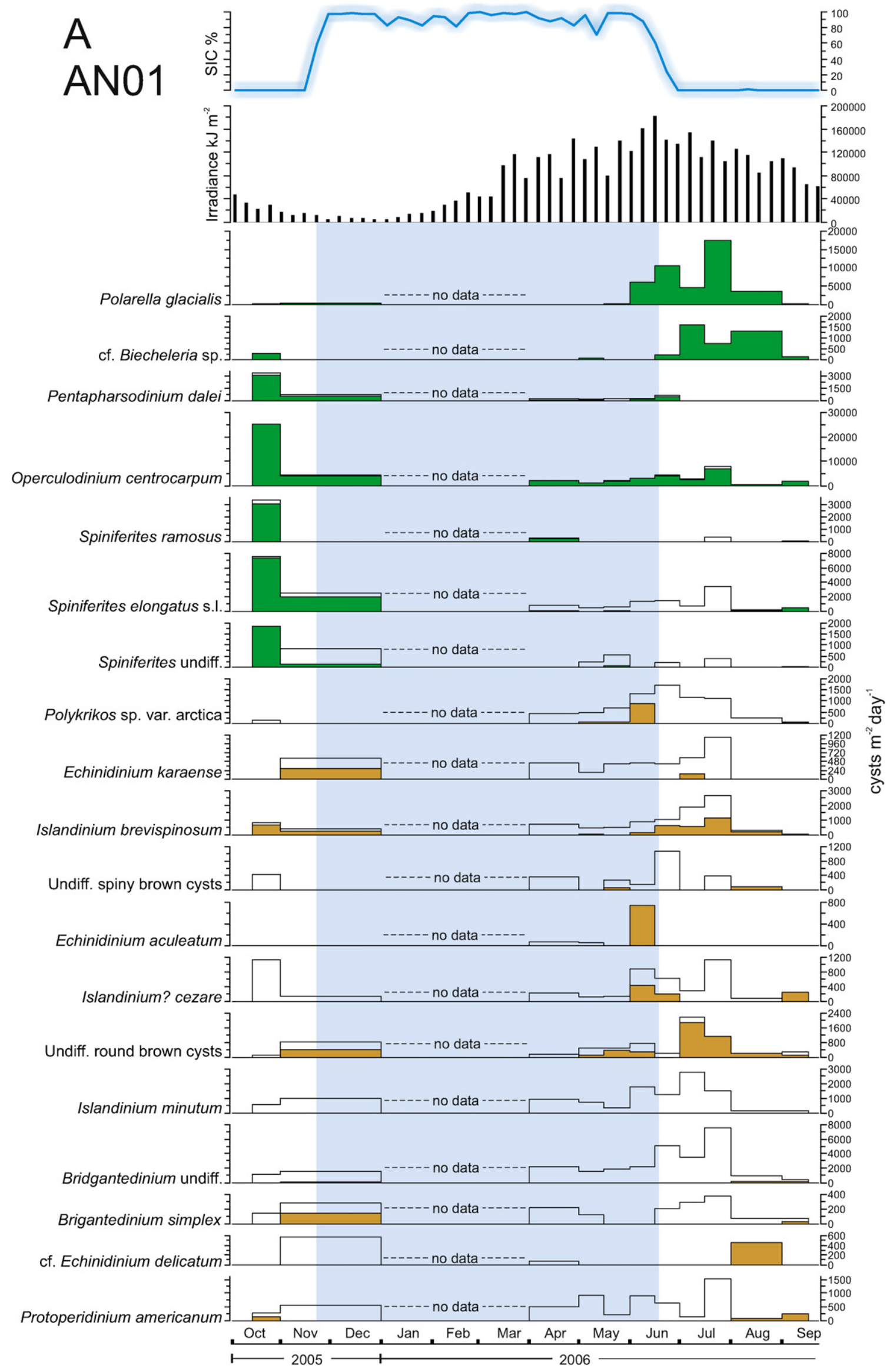




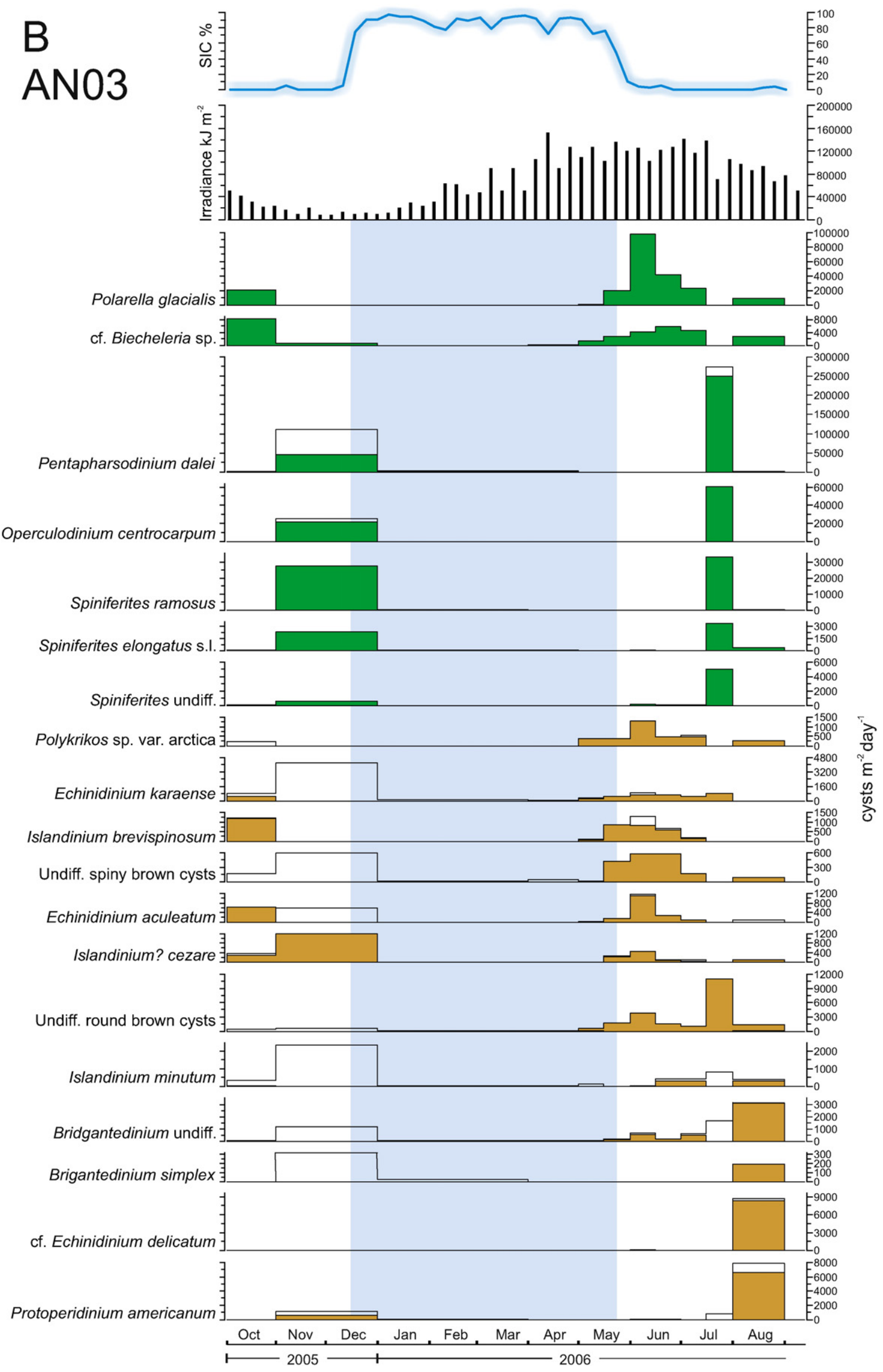

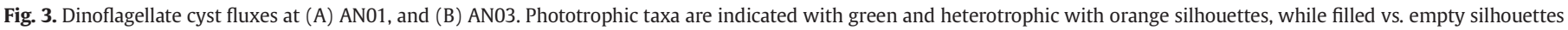

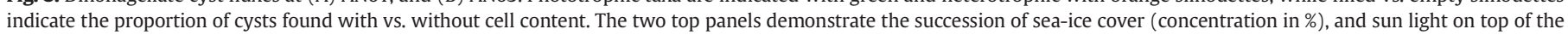
ice (irradiance in $\mathrm{kJ} \mathrm{m}^{-2}$ ), pale blue shading denotes the ice-covered season (SIC >50\%). Note that the X-axis scales are different for AN01 (A) and AN03 (B). 
were exhibited in the species composition, however: cysts of $P$. glacialis and cf. Biecheleria sp. are present in high quantities in the traps but are a minor contributor to surface sediment assemblages (Fig. 7). When compared with each other and with surface sediment data, the two trap sites exhibit highest similarity to the underlying surface sediment, with respect to both fluxes and compositions (Table 4).

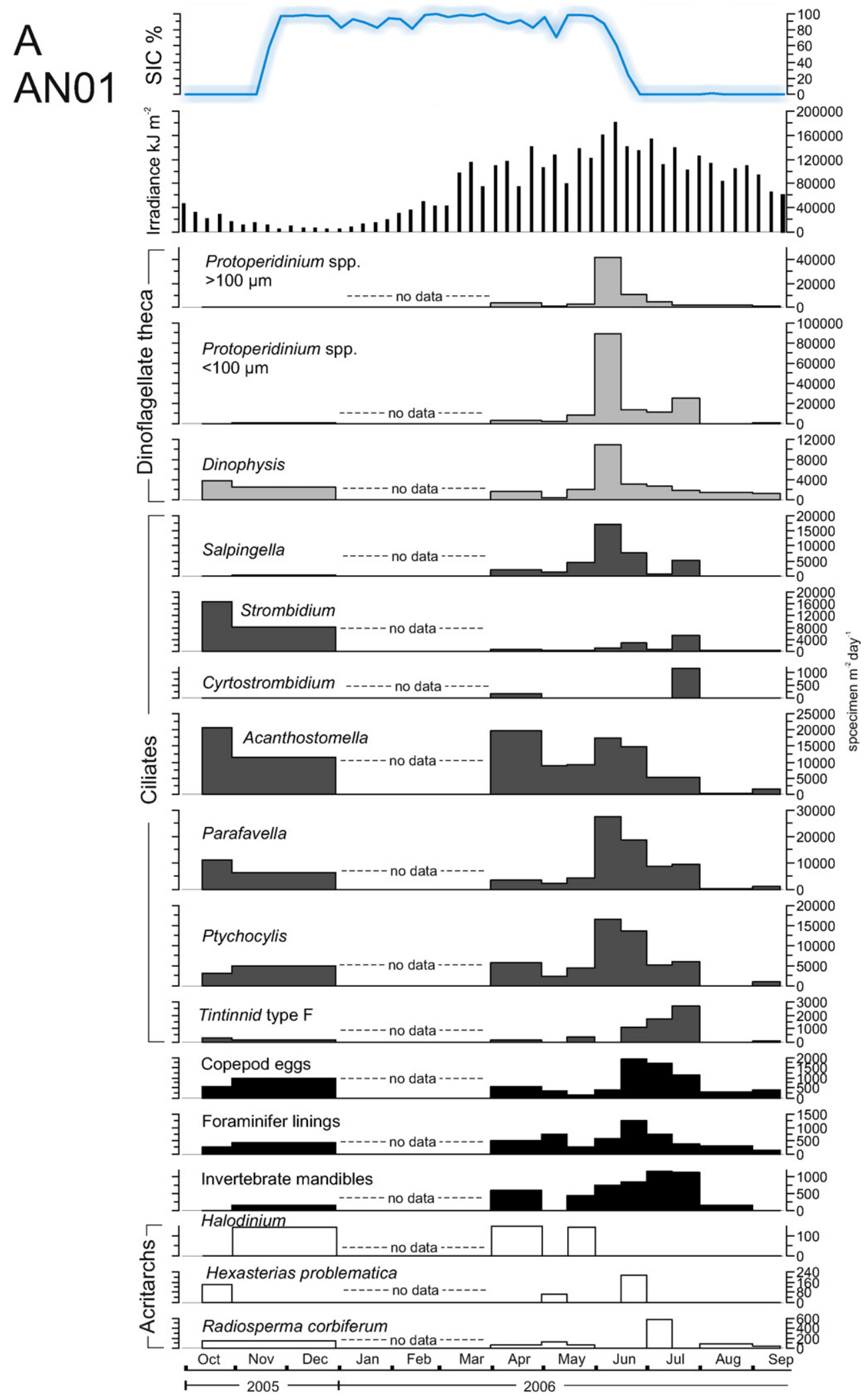

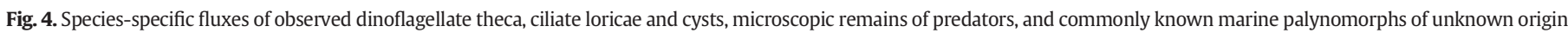
(acritarchs) at (A) AN01, and (B) AN03. Note that the X-axis scales are different for AN01 (A) and AN03 (B). 


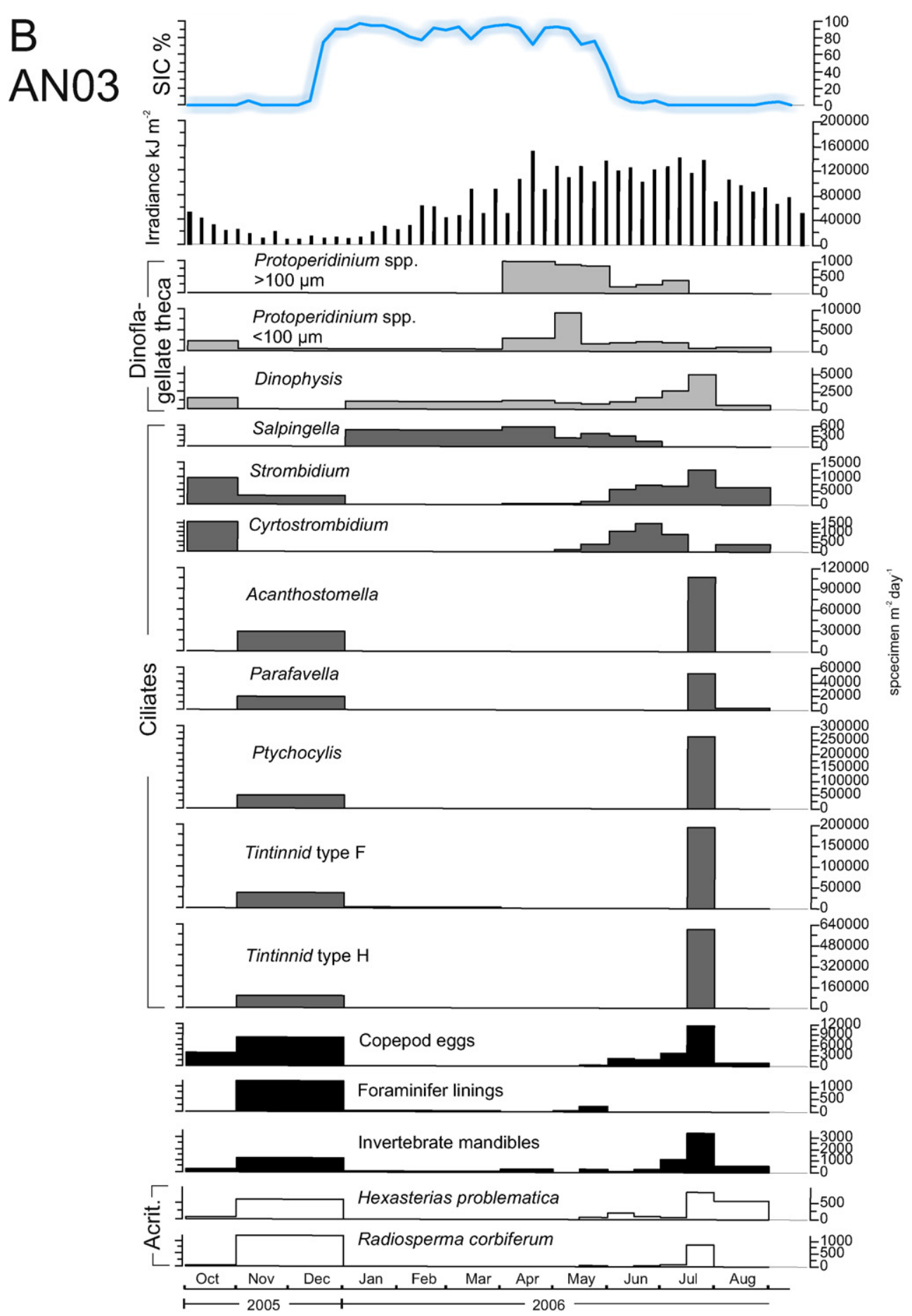

Fig. 4 (continued).

\section{Discussion}

This study presents continuous sequences of seasonal dinoflagellate cyst production at two environmentally different sites of a seasonally ice-covered marine ecosystem. The data allow two overarching messages: (1) seasonal cyst production of high-latitude dinoflagellates exhibits species-specific patterns where the waxing and waning seasonal ice cover governs the beginning and the end of the succession, while site location has most relevance to species-specific flux quantities, and (2) trophic status does not determine the timing of cyst production relative to seasonal light availability, and there is no evidence for either autotrophs or heterotrophs producing cysts in the midwinter of Hudson Bay. These two outcomes and their implications will be discussed in detail below. First, however, the presence and role of reworked sediment material in the trap records will be examined to aid further discussion of the results.

\subsection{Constraints of sediment trap data}

While sediment traps provide a unique method to collect continuous data for seasonal and inter-annual cyst production in situ in an ocean with seasonal ice cover, the assessment of the record may be hampered 


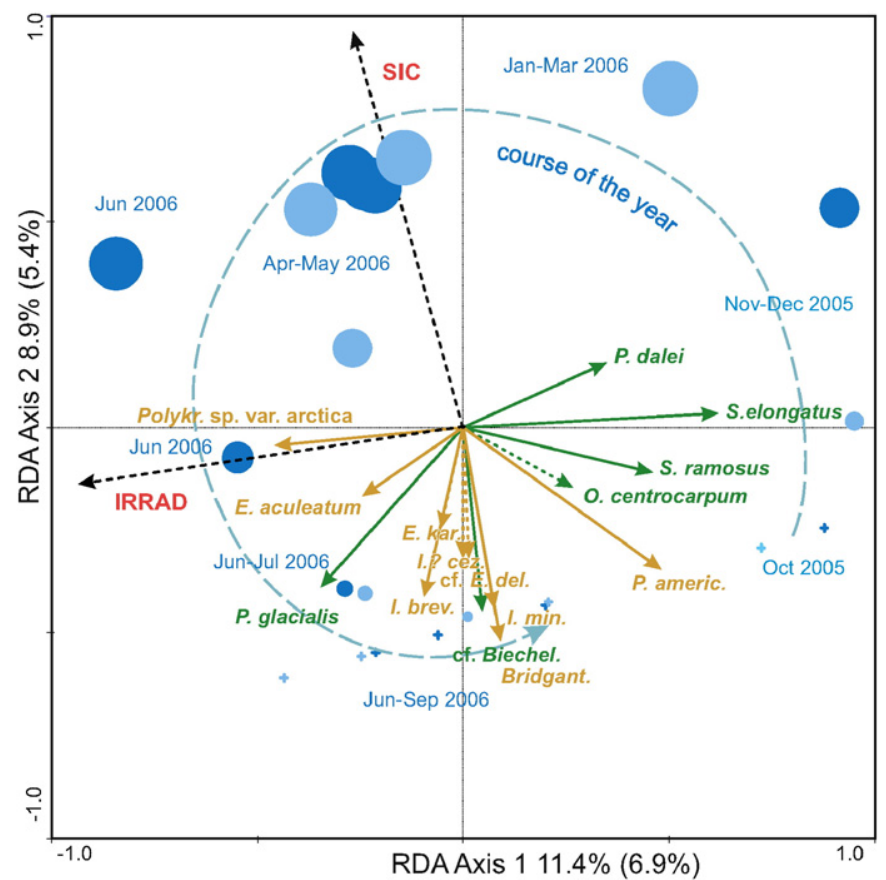

Fig. 5. Correlation biplot of redundancy analysis (RDA) on cyst fluxes (only cysts with cell content) displaying the cyst species responses to sea-ice concentration (SIC) and irradiance (IRRAD). Both sites were included in the analysis: samples from AN01 are marked with darker blue circles/crosses and samples from AN03 with paler blue circles/ crosses, respectively. Increasing size of the circle refers to increasing SIC, and samples marked with crosses indicate SIC $=0 \%$. Dashed blue line sketches the approximate course of the year in Hudson Bay from October 2005 to September 2006 (the arch would be slightly larger for AN01 and slightly smaller for AN03). Green and brown arrows are phototrophic and heterotrophic taxa, respectively. Dashed species arrows refer to species with $<15 \%$ fit in the model. (For interpretation of the references to colour in this figure legend, the reader is referred to the web version of this article.)

by hydrodynamical interactions between currents and traps (trapping efficiency), and collection of resuspended sediments from the seafloor sediments (Gardner et al., 1983; Buesseler et al., 2007). The latter process is particularly relevant in the offshore areas of Hudson Bay where a major share of OM supply appears to comprise resuspension and lateral transport of sediments deposited in shallow coastal water (Kuzyk et al., 2009). Accordingly, one can assume that the vertical particle flux collected by the western offshore trap AN01 is mixed with seabed-derived OM to a larger extent than that of the eastern coastal trap AN03. An additional point for consideration when interpreting sediment trap data is the potential time lag caused by the transport of organic matter from surface waters to the sea floor. Since marine aggregates and phytodetritus generally have sinking rates in the order of dozens and even hundreds of meters per day (Turner, 2002), and as our traps were installed at ca. 100-m depth, in our case this tim lag is probably not relevant.

A few simple features in our data help assess the role of resettled material. First, if cysts are recently produced they are more likely to be found with cell content. Thus, a higher proportion of cysts found with

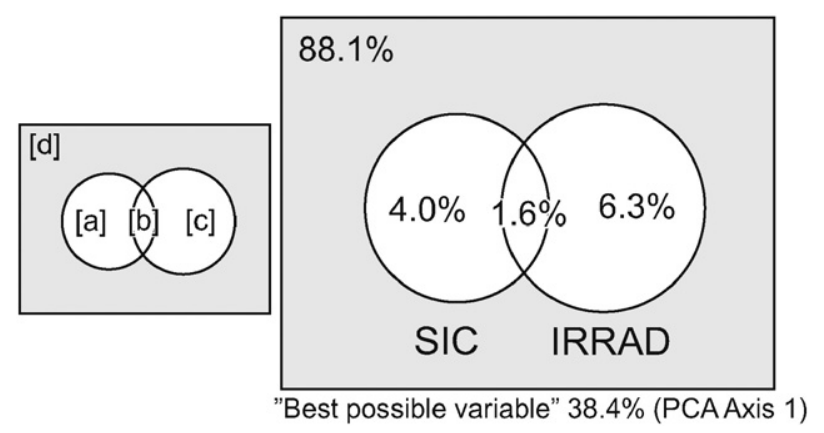

Fig. 6. Partitioning of variance in cyst flux data, explained by sea-ice concentration (SIC) and irradiance (IRRAD). Variation explained by [a] solely SIC, [b] SIC and IRRAD together, [c] IRRAD alone, and [d] unexplained part of variation. Capability of any one theoretical environmental variable to explain the data structure is indicated as the "best possible variable".

cell content indicates a higher probability of the record to be of surface-water origin (Fig. 3, filled vs. empty silhouettes). However, mandatory maturation and hatching times of dinoflagellate cysts vary greatly among species (Pfiester and Anderson, 1987), and even recently produced cysts of species with brief hatching times may be found empty (Price and Pospelova, 2011). These species-specific differences are not always discernible in our data, although phototrophic species are generally found with cell content while heterotrophs are more commonly found empty. At AN01, the cyst fluxes of most heterotrophs and springtime fluxes of Spiniferites species consist predominantly of empty cells (Fig. 3A). Conversely, the AN03 record comprises mainly cysts with cell content, with the exception of fall fluxes of cysts of some heterotrophs (Fig. 3B). This may indicate that at AN01 partially resuspended and laterally transported bottom sediments are mixed with the vertical particle flux. Second, we measured pollen fluxes of terrestrial tree/shrub species that are known to flower during different seasonal time windows. If pollen was derived aerially or via spring and summer riverine inputs, a phenological sequence starting with alder (Alnus), followed by birch (Betula), pine (Pinus) and spruce (Picea), should be discernible (e.g., Nikolov and Helmisaari, 1992; Linkosalo et al., 2009). Corresponding spring sequence is demonstrated distinctly at AN03, while it is vague at AN01 (Fig. 2), further indicating that resuspension of bottom sediments disrupts the AN01 record. However, conifer pollen and Sphagnum spores are also found in the fall (October-December) samples of both sites (Fig. 2), which could be due to either riverine input of pollen stored in soils over the summer, or sediment resuspension. Third, concurrent peaks of all or most of the specimens in the flux record, particularly if simultaneous with high flux totals, points to resuspension. Such occasions are evident at the end of July at AN01 and in November-December at AN03; the latter period takes place in conjunction with very high total matter and POC inputs (Fig. 2B) that could be due to frequent high winds ( $>50 \mathrm{~km} \mathrm{~h}^{-1}$ ) in Kuujjuarrapik (Fig. 1) measured at that time (Lalande and Fortier, 2011). For comparison, during the rest of the study period equally high winds were only recorded sporadically. Based on the three measures discussed above it appears that particularly the AN01 record needs to be interpreted carefully,

Table 3

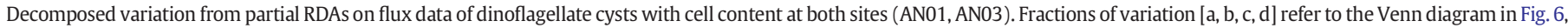
where only adjusted values $\left(R_{\text {adj }}^{2}\right)$ are used (marked in bold). $P$-values were considered significant at $P \leq 0.05$.

\begin{tabular}{|c|c|c|c|c|}
\hline & Proportion (\%) of variation $\left(R^{2}\right)$ & Adjusted proportion (\%) of variation $\left(R^{2}{ }_{\text {adj }}\right)$ & $\%$ of explained variation $\left(R^{2}{ }_{\mathrm{adj}}\right)$ & $P$-value of the model \\
\hline Sea-ice and irradiance $[a+b+c]$ & 20.3 & 11.9 & & 0.02 \\
\hline Sea-ice $[a+b]$ & 10.1 & 5.6 & $47 \%$ & 0.05 \\
\hline Irradiance $[b+c]$ & 12.3 & 7.9 & $66 \%$ & 0.02 \\
\hline [a] & 8 & 4.0 & $34 \%$ & \\
\hline [b] & 2.1 & 1.6 & $13 \%$ & \\
\hline [c] & 10.2 & 6.3 & $53 \%$ & \\
\hline [d] & 79.7 & 88.1 & & \\
\hline
\end{tabular}




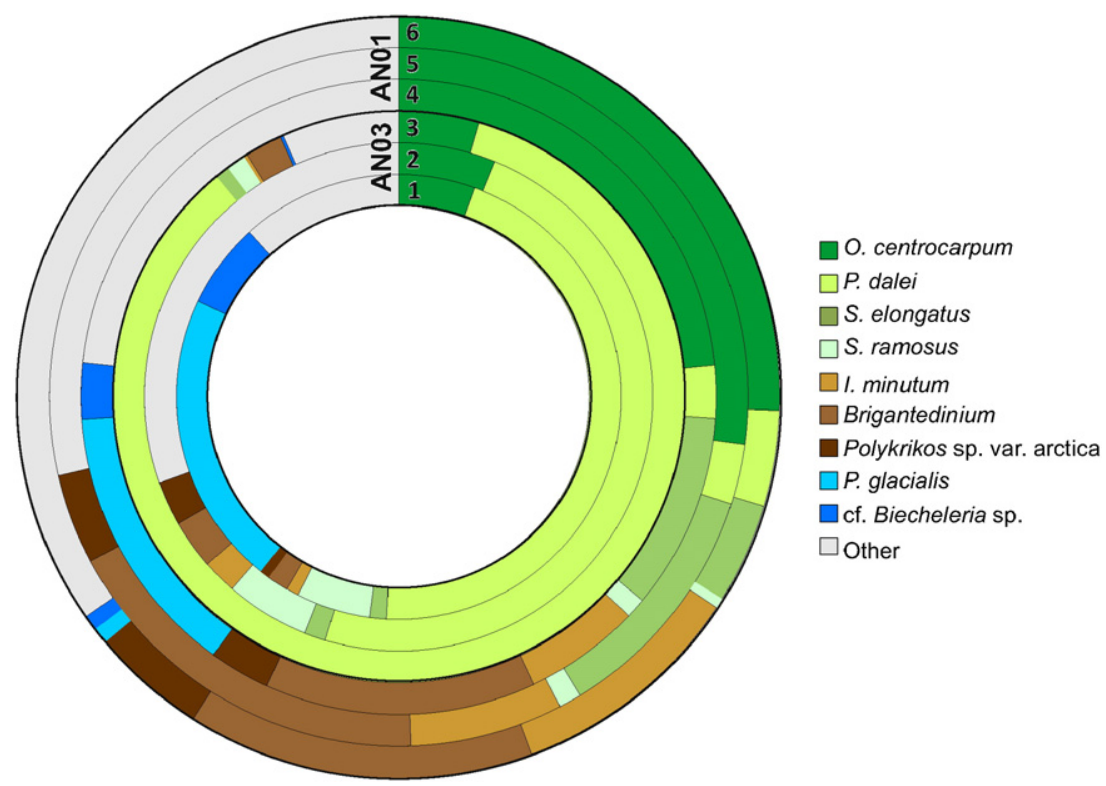

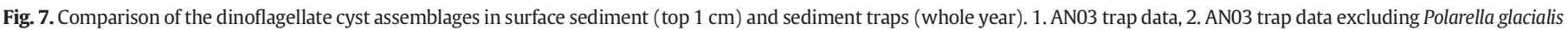

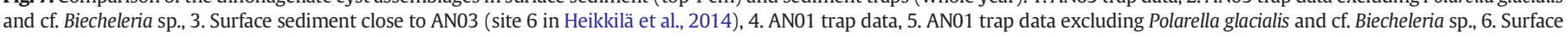

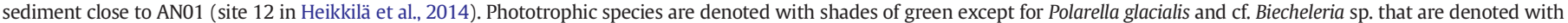
shades of blue; heterotrophic species are colored with shades of brown.

concentrating on the fluxes of cysts with cell content. In addition, the November-December sample at AN03 may contain notable quantities of resuspended material. Overall features of the seasonal cycle in Hudson Bay.

The progression of seasons in Hudson Bay is distinctly delimited by the freeze-up and breakup of sea ice (top panel of Figs. 3, 4, 5, Table 5). As discussed above, the interpretation of our trap records over the fall period 2005 is hampered by potential inclusion of resuspended sediments at both sites. Nevertheless, it is conceivable that some of the key species in the record are late cyst producers, or exhibit multiple cyst production maxima; i.e., one in spring and another in fall (Fig. 3). This behaviour is typical for dinoflagellates in temperate regions, where seasonality is less pronounced and cyst production of phototrophic dinoflagellates, in particular, can take place throughout the year or as multiple seasonal events (Pospelova et al., 2010; Price and Pospelova, 2011). Interestingly, a recent study finds that contemporary lengthening of open-water seasons in the Arctic has led to an appearance of second phytoplankton bloom in the fall, particularly in regions where late season storminess induces vertical mixing, such as the coastal corridor of Hudson Bay (Ardyna et al., 2014). It is hence difficult to discern what proportion of cyst deposition in OctoberDecember 2005 (Fig. 3) is due to storm-induced sediment resuspension, and what proportion is due to actual storm-induced nutrient replenishment in the upper water column leading to successive blooms and cyst production.

The darkest time of the year in Hudson Bay is from November to February when light levels at these latitudes, even at the top of the ice, are extremely low. The only organism in our record that seems to be favoured by this time interval is Salpingella (Fig. 4), a cosmopolitan tintinnid that is also found in under-ice plankton assemblages from the Antarctic (Buck et al., 1992). Salpingella loricae are abundant in winter at site AN03. Interestingly, theca of phototrophic dinoflagellates from the genus Dinophysis are also present during winter, although they are most abundant during the ice breakup and open water season. Most species of Dinophysis are kleptoplastidic mixotrophs, i.e., they could derive their chloroplasts from photosynthesizing ciliates (Minnhagen and Janson, 2006). Dinophysis can also survive months in starved conditions, perhaps because of its ability to assimilate exogenous nitrogen (Hattenrath-Lehmann and Gobler, 2015). However, current knowledge suggests that Dinophysis is obligately mixotrophic and cannot survive long periods without light or prey (Kim et al., 2008). Thus it is somewhat surprising that Dinophysis appears under sea ice throughout the polar night. The pattern seen in our data perhaps demonstrates that as yet unknown survival strategies exist at least in some Dinophysis species, perhaps because they need to sustain their population throughout the year unlike species with a resting

Table 4

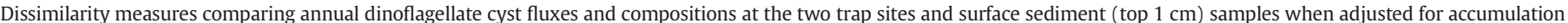
during one year. Distances of trap data and corresponding surface sediment are shown in bold.

\begin{tabular}{|c|c|c|c|c|}
\hline & & & Chord distance & Euclidean distance \\
\hline \multirow[t]{5}{*}{ Flux data } & W trap vs. W sediment & AN01 vs. surface site 12 & 0.41 & $1,567,650$ \\
\hline & E trap vs. E sediment & AN03 vs. surface site 6 & 0.24 & $5,628,130$ \\
\hline & W trap vs. E trap & AN01 vs. AN03 & 1.19 & $14,607,900$ \\
\hline & E trap vs. W sediment & AN01 vs. surface site 6 & 1.30 & $18,772,700$ \\
\hline & W trap vs. E sediment & AN03 vs. surface site 12 & 1.20 & $14,443,100$ \\
\hline \multirow[t]{5}{*}{ Compositional data } & W trap vs. W sediment & AN01 vs. surface site 12 & 0.58 & 21.9 \\
\hline & E trap vs. E sediment & AN03 vs. surface site 6 & 0.47 & 40.5 \\
\hline & W trap vs. E trap & AN01 vs. AN03 & 1.12 & 52.5 \\
\hline & E trap vs. W sediment & AN01 vs. surface site 6 & 1.32 & 83.0 \\
\hline & W trap vs. E sediment & AN03 vs. surface site 12 & 1.25 & 59.6 \\
\hline
\end{tabular}


Table 5

Seasonal responses of cyst species to sea ice regime in Hudson Bay. Life-cycle modes correspond to those in the conceptual Fig. 9.

\begin{tabular}{|c|c|c|c|}
\hline $\begin{array}{l}\text { Life-cycle } \\
\text { mode }\end{array}$ & Season of “cyst rain” & $\begin{array}{l}\text { Season of cyst production/motile } \\
\text { population maximum }\end{array}$ & Example species in Hudson Bay \\
\hline- & Sea-ice covered & Sea-ice covered & None \\
\hline 1,2 & Sea-ice melt & $\begin{array}{l}\text { Sea-ice melt or Sea-ice covered } \\
\text { (sea-ice dwellers) }\end{array}$ & $\begin{array}{l}\text { Polarella glacialis, cf. Biecheleria sp., Polykrikos sp. var. arctica, Islandinium brevispinosum, Islandinium? } \\
\text { cezare, Echinidinium karaense, Echinidinium aculeatum }\end{array}$ \\
\hline 3 & Open water (summer) & Open water (summer) & Pentapharsodinium dalei, Operculodinium centrocarpum, Spiniferites ramosus, Spiniferites elongatus \\
\hline 4 & Open water (fall) & Open water (fall) & Islandinium minutum, Brigantedinium simplex, cf. Echinidinium delicatum, Protoperidinium americanum \\
\hline
\end{tabular}

stage. When irradiance levels rise in April and some light may be transmitted beneath the ice, heterotrophic dinoflagellates of the genus Protoperidinium, including some large $(>100 \mu \mathrm{m})$ species, start to bloom (Fig. 4). Remains of theca belonging to this group are of special interest because many arctic cyst species of unknown motile affinities are suspected to belong to the genus (Table 1). While it is difficult to identify Protoperidinium theca from palynologically treated samples using light microscopy, commonly observed specimens were large and contained pronounced antapical spines, not resembling, e.g., recently described motile stage of I. minutum (Potvin et al., 2013). Polar Protoperidinium species have been observed feeding on ice and ice-edge blooming diatoms in spring (Archer et al., 1996; Levinsen and Nielsen, 2002; Sherr et al., 2013), but there is evidence of Protoperidinium populations in ice ecosystems that feed primarily on bacteria and dead OM (Lessard and Rivkin, 1986). Importantly, Protoperidinium species use a pseudopodial feeding veil, which enables them to ingest organisms that are much larger than themselves, and they may thus be able to survive through times of starvation using storage products (Menden-Deuer et al., 2005). In our records under-ice Protoperidinium species appear concurrently with increasing irradiance levels (Fig. 4), implying that their primary prey consist of early photosynthesizing ice algae, which based on the available data from Hudson Bay comprise mainly pennate diatoms (Tremblay et al., 1989; Michel et al., 1993). Furthermore, Protoperidinium theca fluxes begin weeks before the ice melt, indicating that the fluxes are likely of water column origin. Indeed, in many sea-ice governed systems, ice protist communities consist mainly of diatoms whereas under-ice surface water communities are dominated by flagellates and ciliates (Tremblay et al., 1989; Rintala et al., 2010).

The time around the ice breakup is a very active season in our records with multiple phototrophic (P. glacialis, cf. Biecheleria sp.) and heterotrophic (Polykrikos sp. var. arctica, E. karaense, E. aculeatum, I. brevispinosum) dinoflagellate species exhibiting maximum cyst fluxes (Figs. 3, 5 and 8). Fluxes of Protoperidinium theca are still significant, tintinnid loricae are abundant particularly at site AN01, and cysts of ciliates (Strombidium, Cyrtostrombidium) start emerging at site AN03 (Fig. 4). Seasonally retreating ice edge has been identified as a unique stage for space- and time-transgressive ice algal and phytoplankton blooms that support versatile arctic ecosystems (Leu et al., 2011; Perrette et al., 2011). Together with large amounts of runoff, freshwater input from melting ice creates strong stratification and thus favourable conditions for phytoplankton blooms, also providing nutrients and bloom population seeding. Furthermore, solar irradiance at the sea surface increases as the ice cover shrinks. Most studies of plankton composition in Hudson Bay have been conducted during ship-based programs in summer and fall (Bursa, 1961; Anderson et al., 1981; Harvey et al., 1997; Ferland et al., 2011; Lapoussière et al., 2009), and little is known of springtime dynamics. Existing studies were carried out at the mouth of the Great Whale River in southeastern Hudson Bay, near our trap site AN03. These studies identify spring ice melt as a key successional event, preceded by high chlorophyll levels and algal cell counts in ice, and followed by under-ice phytoplankton blooms and copepod grazing of released ice algae in the water-column (Tremblay et al., 1989; Runge et al., 1991; Michel et al., 1993). The earlier studies did not analyze sympagic and under-ice
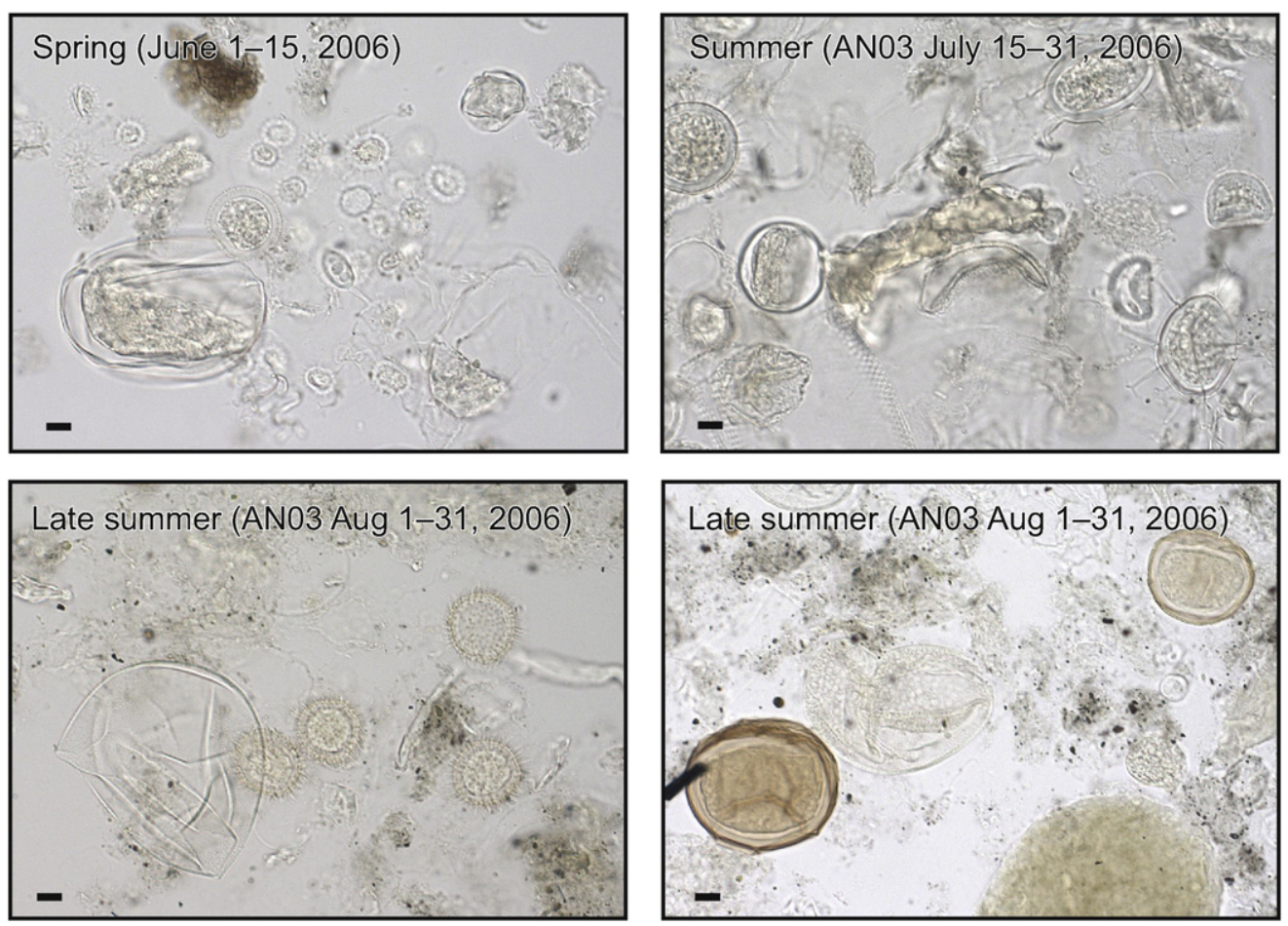

Fig. 8. Examples of seasonal palynomorph assemblages from trap site AN03. 
microzooplankton (i.e., heterotrophic dinoflagellates and tintinnids), but our data suggest that they constitute an important group in the springtime production cycle of Hudson Bay (Figs. 3 and 4).

Our data indicate that none of the dinoflagellate species in our record produce cysts in winter, at least not in the water column, but many do so in spring along with increasing irradiance and ice breakup, while the remainder prefer the successive open-water season (Figs. 3, 5 and 8). It is, however, not possible to distinguish the cyst production events of sea-ice dinoflagellates, since cysts are released to the water column following the sea-ice melt, and may hence appear in the trap records coincidentally with under-ice or ice-edge bloomers (Fig. 9).

\subsection{The role of sea-ice cover and light availability}

Subsequent to determining the fundamental role of life cycle transitions in dinoflagellate bloom dynamics (Dale, 1983; Anderson and Rengefors, 2006), biologists have made substantial efforts to understand the regulation mechanisms of cyst germination following dormancy (excystment) and cyst formation following blooms (encystment). While the processes leading to the formation of resting cysts have only been deciphered for a limited number of species, it seems unequivocal that species-specific controls are at play. For example, encystment is related to nutrient depletion in Gonyaulax tamarensis, Alexandium catenella and Gymnodinium corollarium (Anderson and Lindquist, 1985; Figueroa et al., 2005; Kremp et al., 2009), suboptimal temperature in Scrippsiella hangoei, B. baltica, Gyrodinium uncatenum and Gymnodinium nolleri (Anderson et al., 1985; Ellegaard et al., 1998; Kremp and Parrow, 2006; Kremp et al., 2009), and day length in Scrippsiella rotunda (Sgrosso et al., 2001). Resting stage is generally considered as a means of population continuum over stressful or suboptimal environmental windows, although there is some evidence for population dynamics, such as cell density, playing a role (Uchida, 2001).

As outlined above, neither light-dependent phototrophs nor lightindependent heterotrophs produce cysts in the deep arctic winter of Hudson Bay (Figs. 3 and 5), suggesting bloom quiescence in the dark winter months for all of the species in our records. On the contrary, certain taxa exhibit significant under-ice fluxes along with higher irradiances in the spring (April-June). Such fluxes can result either from surface-water cyst production following under-ice blooms or from the melt-mediated release of sea-ice-dweller cysts to the water column (Fig. 9, Table 5). Furthermore, many species in our record are explicit open-water producers, exhibiting cyst fluxes in June-October. Seasonal light availability thus plays an unquestionable role in dinoflagellate life cycle dynamics in Hudson Bay, but exactly how much irradiance is transmitted through spring sea ice? What conditions select for different life cycle modes of spring and summer cyst producers if not the trophic level?

Recent research has elucidated the significance of ice thickness, surface structure and snow cover for light transmittance and dynamics of seasonal sea ice (Stroeve et al., 2014; Wang et al., 2014). Observations of dense under-ice phytoplankton blooms have been made, e.g., in the Chukchi Sea where ice cover is thinning and the frequency of melt ponds has increased (Arrigo et al., 2012), and under land-fast ice of Canadian Arctic Archipelago through a complete sequence from snow melt and melt-pond formation to ice-cover collapse (Mundy et al., 2014). In Hudson Bay, very close to the trap site AN03, Michel et al. (1993) recorded bottom ice, ice-water interface and under-ice algal blooms during a melt season, demonstrating how spring succession was initiated at the same time as the disappearance of light-limiting snow cover. The ice-algal bloom in early spring was replaced by icewater interface bloomers simultaneously with decreasing snow depth and by under-ice bloomers concurrently with accelerated sea-ice melt (Michel et al., 1988, 1993). Furthermore, there was evidence of seeding from ice to the water column. While most of the ice algal biomass studied by Michel et al. (1993) comprised diatoms, microflagellates exhibited a similar successional pattern. Assuming microflagellates entail dinoflagellates belonging to the size class (clarification is not made in the paper) there is an indication that spring cyst producers in our flux data (Fig. 3) may originate from different compartments of the ice-water continuum and hence exploit different ecological strategies.

P. glacialis is the only spring species in the Hudson Bay record whose ecology is reasonably well-known. In the Antarctic it grows in sea-icebrine channels in early austral spring and produces cysts in response to nitrate depletion (Montresor et al., 1999; Stoecker et al., 2000), it is extremely halotolerant (Stoecker et al., 2000), and survives temperature extremes (Zheng et al., 2012). Cysts of $P$. glacialis, however, do not consist of resistant dinosporin and likely degrade in sediment (Montresor et al., 1999), as evidently happens in Hudson Bay (Fig. 7). Hence, the application of $P$. glacialis as a sedimentary tracer of past sea-ice environments can be hampered by poor preservation. The motile affiliation of the other phototrophic spring cyst producer, $\mathrm{cf}$.
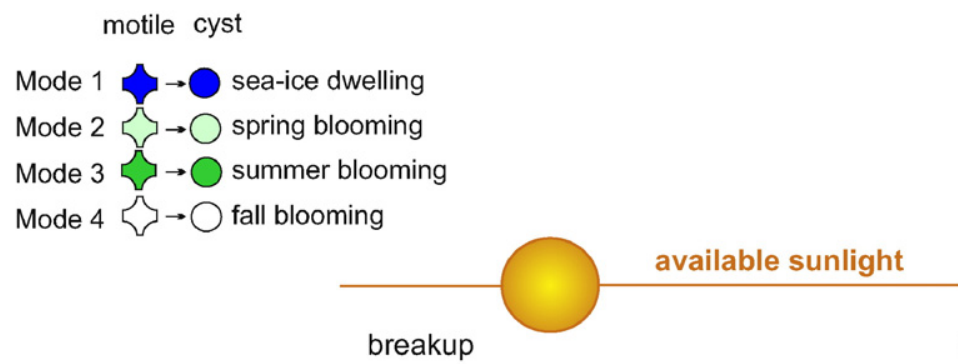

freeze-up

open water

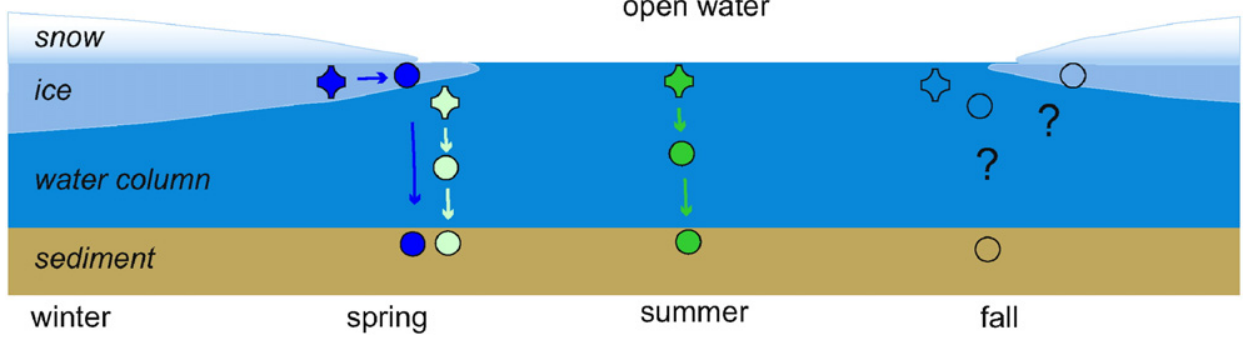

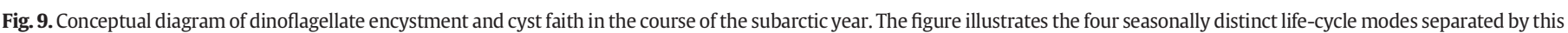

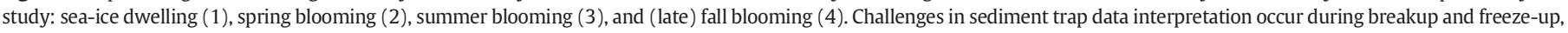

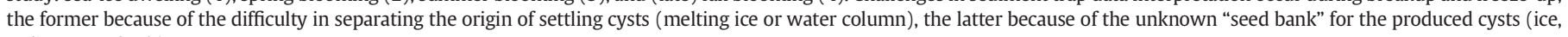
sediment, or both). 
Biecheleria sp., is uncertain, but it closely resembles $B$. baltica, an abundant spring bloomer of the seasonally ice-covered northern Baltic Sea (Kremp et al., 2005). Dense under-ice blooms of $B$. baltica have been observed in salt-stratified cold surface waters of the Baltic Sea (Spilling, 2007), where massive cyst sedimentation events follow the bloom maximum (Heiskanen, 1993). A comparable seasonal encystment pattern is evident in our data from Hudson Bay, where salt-stratification can be similarly created by river plumes penetrating under the sea-ice cover (Legendre et al., 1996). Based on the available ecological data it is likely that the habitat and life cycle strategies of P. glacialis and cf. Biecheleria sp. are divergent, so that in ice-covered ecosystems the former is an ice-dweller and the latter an under-ice bloomer (modes 1 and 2 in Fig. 9), even though the species exhibit roughly comparable seasonal cyst flux patterns (Fig. 3). The other recorded phototrophic species (P. dalei, O. centrocarpum, S. elongatus, S. ramosus) are abundantly found in arctic sediment cores, and exhibit clear signatures of openwater cyst production in our records (modes 3 and 4 in Fig. 9).

Heterotrophic spring cyst producers comprise a peculiar species assemblage with co-occurring fluxes of high-latitude "sea-ice indicators" (Polykrikos sp. var. arctica, E. karaense, I.? cezare) and common low- to mid-latitude cyst species (E. aculeatum, I. brevispinosum) (Fig. 3). The motile stage has not been described for any of these five species despite their common occurrence in marine sediments, and ecological information is thus based on the global distribution of cysts in surface sediment (Zonneveld et al., 2013). Moreover, the classic "sea-ice indicator" I. minutum seems to be, rather surprisingly, a summertime cyst producer in Hudson Bay (corresponding to mode 3 in Fig. 9), indicating that the motile population blooms in surface waters at the peak of the northern summer. This species is most abundantly found in surface sediments from Hudson Strait (Heikkilä et al., 2014), however, and the fluxes in our trap records within Hudson Bay are not very high. Other heterotrophic summertime cyst producers include P. americanum and cosmopolitan species of the genus Brigantedinium (cysts of Protoperidinium species), as well as the spiny brown species cf. E. delicatum. Our trap data thus manifest that cold-water heterotrophs exhibit a variety of life-cycle strategies, and highlight the fact that light conditions are not a common control of their cyst production in Hudson Bay.

It is known from productive marine systems (e.g., upwelling coasts, eutrophic estuaries) that heterotrophic dinoflagellates, particularly those belonging to Protoperidiniaceae, are abundant where and when their predominant prey, diatoms, bloom (Lessard, 1991). Recent comparisons of cyst fluxes with diatom abundance indicate a similar dependency of heterotrophic dinoflagellates on their prey (Pospelova et al., 2010; Zonneveld et al., 2010a; Price and Pospelova, 2011; Bringué et al., 2013). The general preference of heterotrophs for nutrient- and diatom-rich areas within the Hudson Bay system is also reflected by areal distributions of cysts in surface sediments (Heikkilä et al., 2014). An exception to this pattern was exhibited by Polykrikos sp. var. arctica whose cysts were found most abundantly in areas where ice-cover persisted longest (Figs. 3-5 and Panel F in Appendix A, Heikkilä et al., 2014). The possible affiliation with sea ice, or with niche conditions shaped by sea ice, is also indicated by the common occurrence of Polykrikos cysts in surface sediments of arctic regions where seasonal ice-cover duration is close to a year and annual salinity range is pronounced (de Vernal et al., 2001; Kunz-Pirrung, 2001; Zonneveld et al., 2013). Indeed, Polykrikos is one of the common dinoflagellate genera found in sea ice along with Gymnodinium, Gyrodinium, Scrippsiella and Polarella (Stoecker et al., 1993; Garrison et al., 2005; Thomson et al., 2006; Comeau et al., 2013), although to our knowledge, ice-affiliated Polykrikos has only been reported from the Antarctic (Stoecker et al., 1993). It is important to focus on the ecology, habitat and biological affinity of the arctic Polykrikos-type, as the taxon could potentially be an ice dweller. It has to be pointed out that even though the abundance of Polykrikos sp. var. arctica is not related to the amount of nutrients and biogenic silica in the Hudson Bay system (Heikkilä et al., 2014), the species may still be dependent on certain diatom species as prey.
While it is evident that light availability and seasonal sea ice shape the patterns of dinoflagellate blooms and cyst production in Hudson Bay the multivariate analyses presented above suggest that other moderators could be important as well: $12 \%$ of seasonal cyst flux patterns were explained by sea-ice and irradiance (Table 3, Fig. 6). The proportion of unexplained variation is large despite the generally low theoretical probability for a parameter to explain the biological data structure as reflected by the $38 \%$ variance accounted for by PCA (Fig. 6). Sediment trap data can be noisy, and depending on the trap location and weather patterns, laterally transported or resuspended material may enter the sample jars and get mixed with vertically transported particles (see discussion in Section 4.1). At the same time, the moderate explanatory power of SIC and irradiance in explaining the seasonal data structure may indicate that environmental factors other than light availability are important in triggering dinoflagellate blooms and cyst production. As discussed above, such factors entail nutrient and prey availability, both of which are largely controlled by vertical stratification in the Hudson Bay system (Kuzyk et al., 2010). Moreover, diatoms are by far the most dominant and most diverse sympagic protist group, particularly in spring, with over 700 sea-ice dwelling species recorded in the Arctic (Poulin et al., 2011), and diatom blooms thus provide an ample food source for under-ice blooming heterotrophic dinoflagellates recorded in our traps during ice breakup (Fig. 3).

Water temperature and salinity also vary drastically in the course of the subarctic year, and particularly the former has been found an important regulator of encystment for certain dinoflagellates (e.g., von Stosch, 1973; Anderson et al., 1985; Kremp et al., 2009; Figueroa et al., 2011). Surface temperatures of Hudson Bay have been rising since mid-1990s (Galbraith and Larouche, 2011; Hochheim and Barber, 2014), against that trend the years 2005 and 2006 were not anomalously high (Galbraith and Larouche, 2011; Table 3; Supplementary Fig. 1). The available sea surface temperature, salinity and nutrient measurements from Hudson Bay that co-occur with the time frame of this study were taken in late summers 2005 and 2006 (Supplementary Table 1), and hence represent snapshots in time that are not comparable with our bi-weekly to bi-monthly trap data series. However, since southeastern Hudson Bay generally experiences lower salinities, stronger stratification and higher peak season surface temperatures (Barber, 1967; Prinsenberg, 1986a, 1986b; Ferland et al., 2011; Galbraith and Larouche, 2011; Granskog et al., 2011), the differences in general species abundances between the sites (Fig. 7) could be explained by these oceanographic features (see further discussion in Heikkilä et al., 2014).

Importantly, none of the above-mentioned environmental factors operate separately, and sea-ice has a noteworthy role in controlling seasonal sea-surface temperatures, nutrient levels, salinity and water column structure through melt-water mediated salt-stratification in spring, and conversely, through upper water column mixing via iceformation and brine-rejection in fall (Ferland et al., 2011; Granskog et al., 2011).

\subsection{Comparison of the trap signal with surface sediment}

The comparison of trap fluxes with those of the surface sediment demonstrate that both the species diversity and the quantified cyst fluxes in sediment are generally equivalent to the vertical fluxes recorded in the bottom of the water column, lending support to reconstruction of past conditions based on sedimentary dinoflagellate cysts (Fig. 7, Table 4). However, cysts of $P$. glacialis and cf. Biecheleria sp. that are not commonly recorded in sedimentary archives, seem to quickly mineralize after sedimentation. Another deviance is the abundance of $P$. dalei at the sediment surface relative to the trap record in eastern Hudson Bay. P. dalei is a prolific cyst producer in stratified highlatitude waters, such as fjords (Dale, 1976, 1977; Godhe et al., 2001; Howe et al., 2010; Milzer et al., 2013), and it can dominate assemblages in relatively productive high-latitude seas such as Hudson Bay (Radi 
et al., 2001; Marret et al., 2004; Heikkilä et al., 2014). The calculation of annual averages for the traps is based on the record from October 2005 to September 2006, while the 1 -cm surface sediment record represents ca. 20 years of accumulation prior to core collection in September 2005 (Kuzyk et al., 2009). Since inter-annual differences in cyst production are often significant (see e.g., Pospelova et al., 2010; Zonneveld et al., 2010a), discrepancies such as the differing abundances of $P$. dalei in the trap and surface signals may be explained by the temporal mismatch. Furthermore, while it looks likely that $P$. glacialis and cf. Biecheleria sp. do not preserve in downcore records, these species should be surveyed more carefully in any future palynological studies from sea-ice environments.

\subsection{Lessons for palaeo application}

Dinoflagellate cysts are currently one of the most widely applied proxies for late Quaternary sea-ice reconstruction in the Northern Hemisphere along with newly developed biomarker tools (Belt et al., 2007; Belt and Müller, 2013). An extensive modern reference database incorporating over 1400 surface sediment sites has been developed (de Vernal et al., 1997, 2001, 2013) and applied to reconstruct submillennial-scale sea-ice conditions in the Arctic (e.g., Levac et al., 2001; de Vernal and Hillaire-Marcel, 2005; Bonnet et al., 2010; Ledu et al., 2010). Since the reconstructions give quantitative estimates of sea-ice cover (ice-cover in months $\mathrm{yr}^{-1}$, or mean annual concentration $1: 10-10: 10)$, they provide much needed estimates for comparison with modern and predicted sea-ice trends, and for climate model evaluation. Nonetheless, sea-ice reconstructions based on dinoflagellate cysts do not always corroborate commonly observed large-scale temperature trends inferred from other proxies. Validation of reconstruction results and assessment of the causalities in the reconstruction procedure will benefit from the understanding of the ecology and biology of dinoflagellate life cycles.

Our seasonal cyst flux data demonstrate that some of the traditional "sea-ice indicator" species, namely Polykrikos sp. var. arctica, I.? cezare, and E. karaense, exhibit cyst fluxes during ice breakup along with other heterotrophs that are known as temperate species ( $I$. brevispinosum, E. aculeatum) (Table 5). The most abundant and commonly applied "sea-ice indicator" I. minutum, on the other hand, appears unexpectedly as an open-water cyst producer in Hudson Bay together with heterotrophs P. americanum, Brigantedinium spp. and cf. E. delicatum, which indicates a population maximum during the polar summer rather than a direct affiliation with sea ice. Since proxy-based reconstructions are often derived from individual sites (sediment cores) set against a global or hemispheric reference database, the assumption is made that predominant environmental drivers of species distributions and controls of life-cycle transitions are uniform across regions. In consequence, in locations where sea-ice is not a primary control, "sea-ice reconstructions" may reflect other, regionally pivotal environmental controls, such as nutrient and prey availability in the Hudson Bay system.

Interestingly, there is lack of evidence for a uniform seasonal time windows or life-cycle behaviour of commonly applied "sea-ice proxy" species in our data. We do not know, however, whether the seasonal fingerprints of the species in our dataset persist from year to year, or whether the phenological pattern demonstrated in Hudson Bay is repeated in other arctic marine regions. Moreover, distinguishing cysts derived from melting ice from those produced concurrently in the upper water column is a challenge (Fig. 9) and requires on-ice sampling before and during ice breakup to complement the results from sequential trap data. Furthermore, it is not apparent in the trap data if cysts are incorporated into sea-ice during freeze-up (Fig. 9), another question which can only be answered by direct on-ice field work. Establishing species-specific time windows and cues of cyst production for arctic dinoflagellates and exploring their geographic resilience can advance and tune proxy-based reconstruction by redefining appropriate spatial coverages for reference data sets and by providing detailed knowledge of ecological characteristics of cyst production in relation to environmental variables.

\section{Conclusions}

Here we have presented two continuous, annual sequences of dinoflagellate cyst production based on sediment trap data from Hudson Bay to elucidate the seasonal patterns of arctic dinoflagellate encystment and thus enhance the ecological understanding of the proxy. Our data show that overall cyst production is controlled by the sea-ice regime and that sediment cyst assemblages closely resemble those caught by the vertical flux measured in the traps, thus lending support to the use of dinoflagellate cysts as environmental proxies in arctic seas. Furthermore, seasonal time windows of cyst production are speciesspecific, and broadly similar, at the two oceanographically differing sites. Nevertheless, the relation of trophic status to seasonal darkness, i.e., preferential cyst production of heterotrophs over the dark season, was not demonstrated, and the most common sea-ice indicator species I. minutum did not appear as a sea-ice dweller in our dataset. The data here present the first continuous records of cyst production throughout the year in an ice-covered system. Nevertheless, these records should be considered preliminary. A longer period of record, incorporating several years, a wider selection of arctic regions and environmental parameters, would be a key requisite for ecologically robust proxy reconstructions.

\section{Acknowledgements}

We are grateful to the captains and crews of CCGS Amundsen and CCGS Pierre Radisson, and the mooring team technicians for the deployments and recoveries of the sediment traps. National Climate Services Canada is thanked for producing the missing CWEEDS data. We thank the Editor and two reviewers for their constructive comments on the manuscript. This study was supported by ArcticNet, a Network of Centres of Excellence of Canada, and the Academy of Finland (grant no. 251,212 to M.H.). This research was partially supported by the Natural Science and Engineering Research Council of Canada (NSERC Discovery grant to V.P.).

\section{Appendix A. Supplementary data}

Supplementary data to this article can be found online at http://dx. doi.org/10.1016/j.marmicro.2016.02.005.

\section{References}

Adl, S.M., Simpson, A.G.B., Lane, C.E., Lukeš, J., Bass, D., Bowser, S.S., Brown, M.W., Burki, F., Dunthorn, M., Hampl, V., Heiss, A., Hoppenrath, M., Lara, E., le Gall, L., Lynn, D.H., McManus, H., Mitchell, E.A.D., Mozley-Stanridge, S.E., Parfrey, L.W., Pawlowski, J., Rueckert, S., Shadwick, L., Schoch, C.L., Smirnov, A., Spiegel, F.W., 2012. The revised classification of eukaryotes. J. Eukaryot. Microbiol. 59, 429-514.

Anderson, D.M., Lindquist, N.L., 1985. Time-course measurements of phosphorus depletion and cyst formation in the dinoflagellate Gonyaulax tamarensis Lebour. J. Exp. Mar. Biol. Ecol. 86, 1-13.

Anderson, D.M., Rengefors, K., 2006. Community assembly and seasonal succession of marine dinoflagellates in a temperate estuary: the importance of life cycle events. Limnol. Oceanogr. 51, 860-873.

Anderson, J.T., Roff, J.C., 1980. Seston ecology of the surface waters of Hudson Bay. Can. J. Fish. Aquat. Sci. 37, 2242-2253.

Anderson, D.M., Coats, D.W., Tyler, M.A., 1985. Encystment of the dinoflagellate Gyrodinium uncatenum, temperature and nutrient effects. J. Phycol. 21, 200-206.

Anderson, J.T., Roff, J.C., Gerrath, J., 1981. The diatoms and dinoflagellates of Hudson Bay. Can. J. Bot. 59, 1793-1810.

Archambault, P., Snelgrove, P.V.R., Fisher, J.A.D., Gagnon, J.-M., Garbary, D.J., Harvey, M., Kenchington, E.L., Lesage, V., Levesque, M., Lovejoy, C., Mackas, D.L., XMcKindsey, D.L., Nelson, J.R., Pepin, P., Piché, L., Poulin, M., 2010. From sea to sea: Canada's three oceans of biodiversity. PLoS One 5, e12182.

Archer, S., Leakey, R., Burkill, P., Sleigh, M., 1996. Microbial dynamics in coastal waters of East Antarctica: herbivory by heterotrophic dinoflagellates. Mar. Ecol. Prog. Ser. 139, 239-255. 
Ardyna, M., Babin, M., Gosselin, M., Devred, E., Rainville, L., Tremblay, J.-É., 2014. Recent Arctic Ocean sea-ice loss triggers novel fall phytoplankton blooms. Geophys. Res. Lett. (2014GL061047).

Arrigo, K.R., Perovich, D.K., Pickart, R.S., Brown, Z.W., van Dijken, G.L., Lowry, K.E., Mills, M.M., Palmer, M.A., Balch, W.M., Bahr, F., Bates, N.R., Benitez-Nelson, C., Bowler, B., Brownlee, E., Ehn, J.K., Frey, K.E., Garley, R., Laney, S.R., Lubelczyk, L., Mathis, J., Matsuoka, A., Mitchell, B.G., Moore, G.W.K., Ortega-Retuerta, E., Pal, S., Polashenski, C.M., Reynolds, R.A., Schieber, B., Sosik, H.M., Stephens, M., Swift, J.H., 2012. Massive phytoplankton blooms under Arctic Sea ice. Science 336, 1408.

Barber, F.G., 1967. A Contribution to the Oceanography of Hudson Bay, Manuscript Report Series No. 4. Department of Energy, Mines and Resources, Marine Sciences Branch, p. 69.

Belt, S.T., Müller, J., 2013. The Arctic sea ice biomarker IP25: a review of current understanding, recommendations for future research and applications in palaeo sea ice reconstructions. Quat. Sci. Rev. 79, 9-25.

Belt, S.T., Massé, G., Rowland, S.J., Poulin, M., Michel, C., LeBlanc, B., 2007. A novel chemical fossil of palaeo sea ice: IP25. Org. Geochem. 38, 16-27.

Bérard-Therriault, L., Poulin, M., Bossé, L., 1999. Guide d'identification du phytoplancton marin de l'estuaire et du golfe du Saint-Laurent incluant également certains protozoaires. Can. Spec. Publ. Fish. Aquat. Sci. 128, 1-387.

Bluhm, B.A., Gebruk, A.V., Gradinger, R., Hopcroft, R.R., Huettmann, F., Kosobokova, K.N., Sirenko, B.I., Weslawski, J.M., 2011. Arctic marine biodiversity: an update of species richness and examples of biodiversity change. Oceanography 24 $232-248$.

Bogus, K., Mertens, K.N., Lauwaert, J., Harding, I.C., Vrielinck, H., Zonneveld, K.A.F., Versteegh, G.J.M., 2014. Differences in the chemical composition of organic-walled dinoflagellate resting cysts from phototrophic and heterotrophic dinoflagellates. J. Phycol. 50, 254-266.

Bonnet, S., de Vernal, A., Hillaire-Marcel, C., 2010. Variability of sea-surface temperature and sea-ice cover in the Fram Strait over the last two millennia. Mar. Micropaleontol. 74, 59-74.

Borcard, D., Gillet, F., Legendre, P., 2011. Numerical Ecology with R. Springer Science + Business Media, p. 312.

Borcard, D., Legendre, P., Drapeau, P., 1992. Partialling out the spatial component of ecological Variation. Ecology 73, 1045-1055.

Bouimetarhan, I., Dupont, L., Schefuß, E., Mollenhauer, G., Mulitza, S., Zonneveld, K., 2009. Palynological evidence for climatic and oceanic variability off NW Africa during the late Holocene. Quat. Res. 72, 188-197.

Bringué, M., Pospelova, V., Field, D.B., 2014. High resolution sedimentary record of dinoflagellate cysts reflects decadal variability and 20th century warming in the Santa Barbara Basin. Quat. Sci. Rev. 105, 86-101.

Bringué, M., Pospelova, V., Pak, D., 2013. Seasonal production of organic-walled dinoflagellate cysts in an upwelling system: a sediment trap study from the Santa Barbara Basin, California. Mar. Micropaleontol. 100, 34-51.

Buck, C.E., Garrison, D.L., Hopkins, T.L., 1992. Abundance and distribution of tintinnid ciliates in an ice edge zone during the austral autumn. Antarct. Sci. 4, 3-8.

Buesseler, K.O., Antia, A.N., Chen, M., Fowler, S.W., Gardner, W.D., Gustafsson, O., Harada, K., Michaels, A.F., Rutgers van der Loeff, M., Sarin, M., Steinberg, D.K., Trull, T., 2007. An assessment of the use of sediment traps for estimating upper ocean particle fluxes. J. Mar. Res. 65, 345-416.

Burki, F., Shalchian-Tabrizi, K., Minge, M., Skjæveland, Å., Nikolaev, S.I., Jakobsen, K.S., Pawlowski, J., 2007. Phylogenomics reshuffles the eukaryotic supergroups. PLoS One 2, e790.

Bursa, A., 1961. Phytoplankton of the Calanus expeditions in Hudson Bay 1953 and 1954. J. Fish. Res. Board Can. 18, 51-83.

Cavalieri, D.J., Parkinson, C.L., 2012. Arctic sea ice variability and trends, 1979-2010. Cryosphere 6, 881-889.

Cloern, J.E., Jassby, A.D., 2008. Complex seasonal patterns of primary producers at the land-sea interface. Ecol. Lett. 11, 1294-1303.

Comeau, A.M., Philippe, B., Thaler, M., Gosselin, M., Poulin, M., Lovejoy, C., 2013. Protists in Arctic drift and land-fast sea ice. J. Phycol. 49, 229-240.

Dale, B., 1976. Cyst formation, sedimentation, and preservation: factors affecting dinoflagellate assemblages in recent sediments from trondheimsfjord, Norway. Rev. Palaeobot. Palynol. 22, 39-60.

Dale, B., 1977. New observations on Peridinium faeroense Paulsen (1905), and classification of small orthoperidinioid dinoflagellates. Br. Phycol. J. 12, 241-253.

Dale, B., 1983. Dinoflagellate resting cysts: benthic plankton. In: Fryxell, G.A. (Ed.), Survival Strategies of Algae. Cambridge University Press, Cambridge, pp. 69-136.

Dale, B., 1992. Dinoflagellate contributions to the open ocean sediment flux. In: Honjo, S. (Ed.), Dinoflagellate Contributions to the Deep SeaOcean Biocoenosis No. vol. 5. Woods Hole Oceanographic Institution, Woods Hole, pp. 1-32.

de Vernal, A., Hillaire-Marcel, C., 2005. Variability of sea ice cover in the Chukchi Sea (western Arctic Ocean) during the Holocene. Paleoceanography 20, PA4018. http://dx.doi.org/10.1029/2005PA001157.

de Vernal, A., Eynaud, F., Henry, M., Hillaire-Marcel, C., Londeix, L., Mangin, S., Matthiessen, J., Marret, F., Radi, T., Rochon, A., Solignac, S., Turon, J.-L., 2005. Reconstruction of sea-surface conditions at middle to high latitudes of the Northern Hemisphere during the Last Glacial Maximum (LGM) based on dinoflagellate cyst assemblages. Quat. Sci. Rev. 24, 897-924.

de Vernal, A., Goyette, C., Rodrigues, C., 1989. Contribution palynostratigraphique (dinokystes, pollen et spores) à la connaissance de la mer de Champlain: coupe deSaint-Cézaire, Québec. Can. J. Earth Sci. 26, 2450-2464.

de Vernal, A., Henry, M., Matthiessen, J., Mudie, P., Rochon, A., Boessenkool, K., Eynaud, F., Grøsfjeld, K., Guiot, J., Hamel, D., Harland, R., Head, M., Kunz-Pirrung, M., Levac, E., Loucheur, V., Peyron, O., Pospelova, V., Radi, T., Turon, J.L., Voronina, E., 2001. Dinoflagellate cyst assemblages as tracers of sea-surface conditions in the northern North
Atlantic, Arctic and sub-Arctic seas: the new " $\mathrm{n}=677$ " data base and its application for quantitative palaeoceanographic reconstruction. J. Quat. Sci. 16, 681-698.

de Vernal, A., Rochon, A., Fréchette, B., Henry, M., Radi, T., Solignac, S., 2013. Reconstructing past sea ice cover of the Northern Hemisphere from dinocyst assemblages: status of the approach. Quat. Sci. Rev. 79, 122-134.

de Vernal, A., Rochon, A., Turon, J.L., Mathiessen, J., 1997. Organic-walled dinoflagellate cysts: palynological tracers of sea-surface conditions in middle to high latitude marine environment. Geobios 30, 905-920.

Ellegaard, M., 2000. Variations in dinoflagellate cyst morphology under conditions of changing salinity during the last 2000 years in the Limfjord, Denmark. Rev. Palaeobot. Palynol. 109, 65-81.

Ellegaard, M., Kulis, D.M., Anderson, D.M., 1998. Cysts of Danish Gymnodinium nolleri Ellegaard et Moestrup sp. ined. (Dinophyceae): studies on encystment, excystment and toxicity. J. Plankton Res. 20, 1743-1755.

Falkowski, P.G., Oliver, M.J., 2007. Mix and match: how climate selects phytoplankton. Nat. Rev. Microbiol. 5, 813-819.

Falkowski, P.G., Barber, R.T., Smetacek, V., 1998. Biogeochemical controls and feedbacks on ocean primary production. Science $281,200-206$.

Fensome, R.A., Taylor, F.J.R., Norris, G., Sarjeant, W.A.S., Wharton, D.I., Williams, G.L., 1993. A classification of fossil and living dinoflagellates. Micropaleontology 7, 1-351.

Ferland, J., Gosselin, M., Starr, M., 2011. Environmental control of summer primary production in the Hudson Bay system: the role of stratification. J. Mar. Syst. 88, 385-400.

Figueroa, R.I., Bravo, I., Garcés, E., 2005. Effects of nutritional factors and different parental crosses on the encystment and excystment of Alexandrium catenella (Dinophyceae) in culture. Phycologia 44, 658-670.

Figueroa, R.I., Vázquez, J.A., Massanet, A., Murado, M.A., Bravo, I., 2011. Interactive effects of salinity and temperature on planozygote and cyst formation of Alexandrium minutum (Dinophyceae) in culture. J. Phycol. 47, 13-24.

Fujii, R., Matsuoka, K., 2006. Seasonal change of dinoflagellates cyst flux collected in a sediment trap in Omura Bay, West Japan. J. Plankton Res. 28, 131-147.

Galbraith, P.S., Larouche, P., 2011. Sea-surface temperature in Hudson Bay and Hudson Strait in relation to air temperature and ice cover breakup, 1985-2009. J. Mar. Syst. 87, 66-78.

Garcés, E., Bravo, I., Vila, M., Figueroa, R.I., Masó, M., Sampedro, N., 2004. Relationship between vegetative cells and cyst production during Alexandrium minutum bloom in Arenys de Mar harbour (NW Mediterranean). J. Plankton Res. 26, 637-645.

Gardner, W.D., Richardson, M.J., Hinga, K.R., Biscaye, P.E., 1983. Resuspension measured with sediment traps in a high-energy environment. Earth Planet. Sci. Lett. 66, 262-278.

Garrison, D.L., Gibson, A., Coale, S.L., Gowing, M.M., Okolodkov, Y.B., Fritsen, C.H., Jeffries, M.O., 2005. Sea-ice microbial communities in the Ross Sea: autumn and summer biota. Mar. Ecol. Prog. Ser. 300, 39-52.

Godhe, A., Noren, F., Kuylenstierna, M., Ekberg, C., Karlson, B., 2001. Relationship between planktonic dinoflagellate abundance, cyst revocered in sediment traps and environmental factors in the Gullmar Fjord, Sweden. J. Plankton Res. 23, 923-938 (Phycology 46, 202-215).

Granskog, M.A., Kuzyk, Z.Z.A., Azetsu-Scott, K., Macdonald, R.W., 2011. Distributions of runoff, sea-ice melt and brine using $\delta 180$ and salinity data - a new view on freshwater cycling in Hudson Bay. J. Mar. Syst. 88, 362-374.

Guiot, J., de Vernal, A., 2007. Transfer functions: methods for quantitative paleoceanography based on microfossils. In: Hillaire-Marcel, C., de Vernal, A. (Eds.), Proxies in Late Cenozoic Paleoceanography. Elsevier, pp. 523-563.

Hare, A.A., Kuzyk, Z.Z.A., Macdonald, R.W., Sanei, H., Barber, D., Stern, G.A., Wang, F., 2014 Characterization of sedimentary organic matter in recent marine sediments from Hudson Bay, Canada, by Rock-Eval pyrolysis. Org. Geochem. 68, 52-60.

Harland, R., Pudsey, C.J., 1999. Dinoflagellate cysts from sediment traps deployed in the Bellingshausen, Weddell and Scotia seas, Antarctica. Mar. Micropaleontol. 37, 77-99.

Harland, R., Nordberg, K., Filipsson, H.L., 2006. Dinoflagellate cysts and hydrographica change in Gullmar Fjord, west coast of Sweden. Sci. Total Environ. 355, 204-231.

Harvey, M., Therriault, J.-C., Simard, N., 1997. Late-summer distribution of phytoplankton in relation to water mass characteristics in Hudson Bay and Hudson Strait (Canada) Can. J. Fish. Aquat. Sci. 54, 1937-1952.

Hattenrath-Lehmann, T., Gobler, C.J., 2015. The contribution of inorganic and organic nutrients to the growth of a North American isolate of the mixotrophic dinoflagellate, Dinophysis acuminata. Limnology and Oceanography 60, 1588-1603.

Head, M.J., 1996. Modern dinoflagellate cysts and their biological affinities. In: Jansonius, J., McGregor, D.C. (Eds.), Palynology: Principles and Applications. American Association of Stratigraphic Palynologists Foundation, Dallas, pp. 1197-1248.

Head, M.J., Harland, R., Matthiessen, J., 2001. Cold marine indicators of the late Quaternary: the new dinoflagellate cystgenus Islandinium and related morphotypes. J. Quat. Sci. 16, 621-636.

Heikkilä, M., Pospelova, V., Hochheim, K.P., Kuzyk, Z.Z.A., Stern, G.A., Barber, D.G., Macdonald, R.W., 2014. Surface sediment dinoflagellate cysts from the Hudson Bay system and their relation to freshwater and nutrient cycling. Mar. Micropaleontol. 106, 79-109.

Heiskanen, A.S., 1993. Mass encystment and sinking of dinoflagellates during a spring bloom. Mar. Biol. 116, 161-167.

Hill, M.O., Gauch, H.G.J., 1980. Detrended correspondence analysis: an improved ordination technique. Vegetatio 42, 47-58.

Hochheim, K.P., Barber, D.G., 2014. An update on the ice climatology of the Hudson Bay system. Arct. Antarct. Alp. Res. 46, 66-83.

Howe, J.A., Harland, R., Cottier, F.R., Brand, T., Willis, K.J., Berge, J.R., Grøsfjeld, K., Eriksson, A., 2010. Dinoflagellate cysts as proxies for palaeoceanographic conditions in Arctic fjords. Geol. Soc. Lond., Spec. Publ. 344, 61-74. 
Ingram, R.G., Prinsenberg, S., 1998. Coastal oceanography of Hudson Bay and surrounding eastern Canadian Arctic waters. In: Robinson, A.R., Brink, K.H. (Eds.), The Sea: The Global Coastal Ocean, Regional Studies and Syntheses. Wiley, New York, pp. 835-862.

Ishikawa, A., Taniguchi, A., 1996. Contribution of benthic cysts to the population dynamics of Scrippsiella spp. (Dinophyceae) in Onagawa Bay, northeast Japan. Mar. Ecol. Prog. Ser. 140, 169-178.

Jeong, H.J., Yoo, W.D., Kim, J.S., Seong, K.A., Kang, S.N., Kim, T.H., 2010. Growth, feeding and ecological roles of the mixotrophic and heterotrophic dinoflagellates in marine planktonic food webs. Ocean Sci. J. 45, 65-91.

Juggins, S., 2013. Quantitative reconstructions in palaeolimnology: new paradigm or sick science? Quat. Sci. Rev. 64, 20-32.

Kim, S., Kang, Y.G., Kim, H.S., Yih, W., Coats, D.W., Park, M.G., 2008. Growth and grazing responses of the mixotrophic dinoflagellate Dinophysis acuminata as functions of light intensity and prey concentration. Aquat. Microb. Ecol. 51, 301-310.

Kremp, A., 2013. Diversity of dinoflagellate life cycles: facets and implications of complex strategies. In: Lewis, J.M., Marret, F., Bradley, L. (Eds.), Biological and Geological Perspectives of Dinoflagellates. The Micropaleontological Society, Geological Society, London, pp. 197-205.

Kremp, A., Parrow, M.W., 2006. Evidence for asexual resting cysts in the life cycle of the marine peridinoid dinoflagellate, Scrippsiella hangoei. J. Phycol. 42, 400-409.

Kremp, A., Elbrachter, M., Schweikert, M., Wolny, J.L, Gottschling M., 2005. Woloszynskia halophila (Biecheler) comb. nov.: A bloom-forming cold-water dinoflagellate co-occurring with Scrippsiella hangoei (Dinophyceae) in the Baltic Sea. J. Phycol. 41, 629-642.

Kremp, A., Rengefors, K., Montresor, M., 2009. Species-specific encystment patterns in three Baltic cold-water dinoflagellates: the role of multiple cues in resting cyst formation. Limnol. Oceanogr. 54, 1125-1138.

Kunz-Pirrung, M., 1998. Rekonstruktion der Oberflächenwassermassen der östlichen Laptevsee im Holozän anhand der aquatischen Palynomorphen. Reports on Pola Res. 1-117.

Kunz-Pirrung, M., 2001. Dinoflagellate cyst assemblages in surface sediments of the Laptev Sea region (Arctic Ocean) and their relationship to hydrographic conditions. J. Quat. Sci. 16, 637-649.

Kuzyk, Z.Z.A., Macdonald, R.W., Johannessen, S.C., Gobeil, C., Stern, G.A., 2009. Towards a sediment and organic carbon budget for Hudson Bay. Mar. Geol. 264, 190-208.

Kuzyk, Z.Z.A., Macdonald, R.W., Stern, G.A., Gobeil, C., 2011. Inferences about the modern organic carbon cycle from diagenesis of redox-sensitive elements in Hudson Bay. J. Mar. Syst. 88, 451-462.

Kuzyk, Z.Z.A., Macdonald, R.W., Tremblay, J.-È., Stern, G.A., 2010. Elemental and stable isotopic constraints on river influence and patterns of nitrogen cycling and biological productivity in Hudson Bay. Cont. Shelf Res. 30, 163-176.

Lalande, C., Fortier, L., 2011. Downward particulate organic carbon export and jellyfis blooms in southeastern Hudson bay. J. Mar. Syst. 88, 446-450.

Lapoussière, A., Michel, C., Gosselin, M., Poulin, M., 2009. Spatial variability in organic material sinking export in the Hudson Bay system, Canada, during fall. Cont. Shelf Res. $29,1276-1288$.

Lapoussière, A., Michel, C., Gosselin, M., Poulin, M., Martin, J., Tremblay, J.-É., 2013. Primary production and sinking export during fall in the Hudson Bay system, Canada. Cont. Shelf Res. 52, 62-72.

Ledu, D., Rochon, A., de Vernal, A., Barletta, F., St-Onge, G., 2010. Holocene sea ice history and climate variability along the main axis of the Northwest Passage, Canadian Arctic Paleoceanography 25.

Legendre, L., Robineau, B., Gosselin, M., Michel, C., Ingram, R.G., Fortier, L., Therriault, J.-C. Demers, S., Monti, D., 1996. Impact of freshwater on a subarctic coastal ecosystem under seasonal sea ice (southeastern Hudson Bay, Canada) II. Production and export of microalgae. J. Mar. Syst. 7, 233-250.

Lentin, J.K., Williams, G.L., 1993. Fossil dinoflagellates: indexto genera and species. Contribution Series 28. American Association of Stratigraphic Palynologists. College Station, TX.

Lessard, E., 1991. The trophic role of heterotrophic dinoflagellates in diverse marine environments. Mar. Microb. Food Webs 5, 49-58.

Lessard, E.J., Rivkin, R.B., 1986. Nutrition of microzooplankton and macrozooplankton from McMurdo Sound. Antarct. J. US 21, 187-188.

Leu, E., Søreide, J.E., Hessen, D.O., Falk-Petersen, S., Berge, J., 2011. Consequences of changing sea-ice cover for primary and secondary producers in the European Arctic shelf seas: timing, quantity, and quality. Prog. Oceanogr. 90, 18-32.

Levac, E., Vernal, A.D., Blake Jr., W., 2001. Sea-surface conditions in northernmost Baffin Bay during the Holocene: palynological evidence. J. Quat. Sci. 16, 353-363.

Levinsen, H., Nielsen, T.G., 2002. The trophic role of marine pelagic ciliates and heterotrophic dinoflagellates in arctic and temperate coastal ecosystems: a cross-latitude comparison. Limnol. Oceanogr. 47, 427-439.

Linkosalo, T., Häkkinen, R., Terhivuo, J., Tuomenvirta, H., Hari, P., 2009. The time series of flowering and leaf bud burst of boreal trees (1846-2005) support the direct temperature observations of climatic warming. Agric. For. Meteorol. 149, 453-461

Lynn, D.H., 2008. The Ciliated Protozoa: Characterization, Classification, and Guide to the Literature. Springer, Dordrecht, the Netherlands (605 pp.).

Margalef, R., 1978. Life-forms of phytoplankton as survival alternatives in an unstable environment. Oceanol. Acta 1, 493-509.

Marinov, I., Doney, S.C., Lima, I.D., 2010. Response of ocean phytoplankton community structure to climate change over the 21st century: partitioning the effects of nutrients, temperature and light. Biogeosciences 7, 3941-3959.

Marret, F., Eiríksson, J., Knudsen, K.L., Turond, J.-L., Scourse, J.D., 2004. Distribution of dinoflagellate cyst assemblages in surface sediments from the northern and western shelf of Iceland. Rev. Palaeobot. Palynol. 128, 35-53.
Matthiessen, J., de Vernal, A, Head, M., Okolodkov, Y, Zonneveld, K.A.F., Harland, R., 2005. Modern organic-walled dinoflagellate cysts in Arctic marine environments and their (paleo-)environmental significance. Paläontol. Z. 79, 3-51.

Meier, W., Fetterer, F., Savoie, M., Mallory, S., Duerr, R., Stroeve, J., 2013. NOAA/NSIDC Climate Data Record of Passive Microwave Sea Ice Concentration, Version 2. National Snow and Ice Data Center, Boulder, Colorado, USA

Menden-Deuer, S., Lessard, E.J., Satterberg, J., GrÃ¹/4nbaum, D., 2005. Growth rates and starvation survival of three species of the pallium-feeding, thecate dinoflagellate genus protoperidinium. Aquat. Microb. Ecol. 41, 145-152.

Mertens, K.N., Price, A.M., Pospelova, V., 2012. Determining the absolute abundance of dinoflagellate cysts in recent marine sediments II: further tests of the Lycopodium marker-grain method. Rev. Palaeobot. Palynol. 184, 74-81.

Mertens, K.N., Verhoeven, K., Verleye, T., Louwye, S., Amorim, A., Ribeiro, S., Deaf, A.S., Harding, I.C., De Schepper, S., González, C., Kodrans-Nsiah, M., de Vernal, A., Henry, M., Radi, T., Dybkjaer, K., Poulsen, N.E., Feist-Burkhardt, S., Chitolie, J., HeilmannClausen, C., Londeix, L., Turon, J.-L., Marret, F., Matthiessen, J., McCarthy, F.M.G., Prasad, V., Pospelova, V., Kyffin Hughes, J.E., Riding, J.B., Rochon, A., Sangiorgi, F., Welters, N., Sinclair, N., Thun, C., Soliman, A., Van Nieuwenhove, N., Vink, A., Young, M., 2009. Determining the absolute abundance of dinoflagellate cysts in recent marine sediments: the Lycopodium marker-grain method put to the test. Rev. Palaeobot. Palynol. 157, 238-252.

Meunier, A., 1910. Microplankton des Mers de Barents et de Kara, Campagne arctique de 1907 vol. 2. Bulens, Bruxelles.

Michel, C., Legendre, L., Demers, S., Therriault, J.-C., 1988. Photoadaptation of sea-ice microalgae in springtime: photosynthesis and carboxylating enzymes. Mar. Ecol. Prog. Ser. 50, 177-185.

Michel, C., Legendre, L., Therriault, J.-C., Demers, S., Vandevelde, T., 1993. Springtime coupling between ice algal and phytoplankton assemblages in southeastern Hudson Bay, Canadian Arctic. Polar Biol. 13, 441-449.

Milzer, G., Giraudeau, J., Faust, J., Knies, J., Eynaud, F., Rühlemann, C., 2013. Spatial distribution of benthic foraminiferal stable isotopes and dinocyst assemblages in surface sediments of the Trondheimsfjord, central Norway. Biogeosciences 10, 4433-4448.

Minnhagen, S., Janson, S., 2006. Genetic analyses of Dinophysis spp. support kleptoplastidy. FEMS Microbiol. Ecol. 57, 47-54

Moestrup, Ø., Lindberg, K., Daugbjerg, N., 2009. Studies on woloszynskioid dinoflagellates IV: the genus Biecheleria gen. nov. Phycol. Res. 57, 203-220.

Montresor, M., Lovejoy, C., Orsini, Procaccini, G., Roy, S., 2003. Bipolar distribution of the cyst-forming dinoflagellate Polarella glacialis. Polar Biol. 26, 186-194.

Montresor, M., Procaccini, G., Stoecker, D.K., 1999. Polarella glacialis, gen. nov., sp. nov. (Dinophyceae): Suessiaceae are still alive! J. Phycol. 35, 186-197.

Montresor, M., Zingone, A., Sarno, D., 1998. Dinoflagellate cyst production at a coastal Mediterranean site. J. Plankton Res. 20, 2291-2312.

Mudie, P.J., Rochon, A., 2001. Distribution of dinoflagellate cysts in the Canadian Arctic marine region. J. Quat. Sci. 16, 603-620.

Mundy, C., Gosselin, M., Gratton, Y., Brown, K., Galindo, V., Campbell, K., Levasseur, M., Barber, D., Papakyriakou, T., Bélanger, S., 2014. Role of environmental factors on phytoplankton bloom initiation under landfast sea ice in Resolute Passage, Canada. Mar. Ecol. Prog. Ser. 497, 39-49.

Nikolov, N., Helmisaari, H., 1992. Silvics of the circumpolar boreal forest tree species. In: Shugart, H.H., Leemans, R., Bonan, G.B. (Eds.), A Systems Analysis of the Global Boreal Forest. Cambridge University Press, Cambridge, pp. 13-84.

Peres-Neto, P.R., Legendre, P., Dray, S., Borcard, D., 2006. Variance partitioning of species data matrices: estimation and comparison of fractions. Ecology 87. 2614-2625.

Perrette, M., Yool, A., Quartly, G.D., Popova, E.E., 2011. Near-ubiquity of ice-edge blooms in the Arctic. Biogeosciences 8, 515-524.

Pfiester, L.A., Anderson, D.M., 1987. Dinoflagellate reproduction. In: Taylor, F.J.R. (Ed.), The Biology of Dinoflagellates. Blackwell Scientific, Oxford, pp. 611-648.

Pieńkowski, A.J., Mudie, P.J., England, J.H., Smith, J.N., Furze, M.F.A., 2011. Late Holocene environmental conditions in Coronation Gulf, southwestern Canadian Arctic Archipelago: evidence from dinoflagellate cysts, other non-pollen palynomorphs, and pollen. J. Quat. Sci. 26, 839-853.

Pitcher, G.C., Joyce, L.B., 2009. Dinoflagellate cyst production on the southern Namaqua shelf of the Benguela upwelling system. J. Plankton Res. 31, 865-875.

Pospelova, V., Chmura, G.L., Boothman, W.S., Latimer, J.S., 2005. Spatial distribution of modern dinoflagellate cysts in polluted estuarine sediments from Buzzards Bay (Massachusetts, USA) embayments. Mar. Ecol. Prog. Ser. 292, 23-40.

Pospelova, V., Esenkulova, S., Johannessen, S.C., O'Brien, M.C., Macdonald, R., 2010. Organic-walled dinoflagellate cyst production, composition and flux from 1996 to 1998 in the central Strait of Georgia (BC, Canada): a sediment trap study. Mar. Micropaleontol. 75, 17-37.

Pospelova, V., Head, M.J., 2002. Islandinium brevispinosum sp. nov. (Dinoflagellata), a new organic-walled dinoflagellate cyst from modern estuarine sediments of New England (USA). J. Phycol. 38, 593-601.

Pospelova, V., Pedersen, T.F., de Vernal, A., 2006. Dinoflagellate cysts as indicators of climatic and oceanographic changes during the past $40 \mathrm{kyr}$ in the Santa Barbara Basin, southern California. Paleoceanography 21. http://dx.doi.org/10.1029/ 2005PA001251.

Potvin, É, Rochon, A., Lovejoy, C., 2013. Cyst-theca relationship of the arctic dinoflagellate cyst Islandinium minutum (Dinophyceae) and phylogenetic position based on SSU rDNA and LSU rDNA. J. Phycol. 49, 848-866.

Poulin, M., Daugbjerg N., Gradinger, R, Ilyash, L, Ratkova, T, von Quillfeldt, C, 2011. The pan-Arctic biodiversity of marine pelagic and sea-ice unicellular eukaryotes: a firstattempt assessment. Mar. Biodivers. 41, 13-28.

Prebble, J.G., Crouch, E.M., Carter, L., Cortese, G., Nodder, S.D., 2013. Dinoflagellate cysts from two sediment traps east of New Zealand. Mar. Micropaleontol. 104, 25-37. 
Price, A., Pospelova, V., 2011. High-resolution sediment trap study of organic-walled dinoflagellate cyst production and biogenic silica flux in Saanich Inlet (BC, Canada). Mar. Micropaleontol. 80, 18-43.

Price, A.M., Mertens, K.N., Pospelova, V., Pedersen, T.F., Ganeshram, R.S., 2013. Late Quaternary climatic and oceanographic changes in the Northeast Pacific as recorded by dinoflagellate cysts from Guaymas Basin, Gulf of California (Mexico). Paleoceanography 28, 200-212.

Prinsenberg, S.J., 1984. Freshwater contents and heat budgets of James Bay and Hudson Bay. Cont. Shelf Res. 3, 191-200.

Prinsenberg, S.J., 1986a. The circulation pattern and current structure of Hudson Bay. In: Martini, I.P. (Ed.), Canadian Inland Seas. Elsevier, pp. 187-204.

Prinsenberg, S.J., 1986b. Salinity and temperature distribution of Hudson Bay and James Bay. In: Martini, I.P. (Ed.), Canadian Inland Seas. Elsevier, pp. 163-186.

Radi, T., Vernal, A.d., Peyron, O., 2001. Relationships between dinoflagellate cyst assemblages in surface sediment and hydrographic conditions in the Bering and Chukchi seas. J. Quat. Sci. 16, 667-680.

Rintala, J.-M., Piiparinen, J., Uusikivi, J., 2010. Drift-ice and under-ice water communities in the Gulf of Bothnia (Baltic Sea). Polar Biol. 33, 179-191.

Rochon, A., 2009. The Ecology and Biological Affinity of Arctic Dinoflagellates and Their Paleoceanographical Significance in the Canadian High Arctic. From Deep-Sea to Coastal Zones: Methods-Techniques for Studying Paleoenvironments. IOP Conference Series: Earth and Environmental Science 5.

Rochon, A., de Vernal, A., Sejrup, H.-P., Haflidason, H., 1998. Palynological evidence of climatic and oceanographic changes in the North Sea during the Last Deglaciation. Quat. Res. 49, 197-207.

Rochon, A., de Vernal, A., Turon, J.L., Matthiessen, J., Head, M.J., 1999. Distribution of Recent Dinoflagellate Cysts in Surface Sediments from the North Atlantic Ocean and Adjacent Seas in Relation to Sea-surface Parameters. American Association of Stratigraphic Palynologists Foundation, Dallas, TX, p. 152.

Roff, J.C., Legendre, L., 1986. Physico-chemical and biological oceanography of Hudson Bay. In: Martini, I.P. (Ed.), Canadian Inland Seas. Elsevier, Amsterdam, pp. 265-291.

Runge, J., Therriault, J.C., Legendre, L., Ingram, R., Demers, S., 1991. Coupling between ice microalgal productivity and the pelagic, metazoan food web in southeastern Hudson Bay: a synthesis of results. Polar Res. 10, 325-338.

Sakshaug, E., 2004. Primary and secondary production in the Arctic Seas. In: Stein, R., Macdonald, R.W. (Eds.), The Organic Carbon Cycle in the Arctic Ocean. Springer, Berlin, pp. 57-81.

Serreze, M.C., Holland, M.M., Stroeve, J., 2007. Perspectives on the Arctic's shrinking seaice cover. Science 315, 1533-1536.

Sgrosso, S., Esposito, F., Montresor, M., 2001. Temperature and daylength regulate encystment in calcareous cyst-forming dinoflagellates. Mar. Ecol. Prog. Ser. 211, 77-87.

Sherr, E.B., Sherr, B.F., Ross, C., 2013. Microzooplankton grazing impact in the Bering Sea during spring sea ice conditions. Deep-Sea Res. II Top. Stud. Oceanogr. 94, 57-67.

Shin, H.H., Park, J.S., Kim, Y.-O., Baek, S.H., Lim, D., Yoon, Y.H., 2012. Dinoflagellate cyst production and flux in Gamak Bay, Korea: a sediment trap study. Mar. Micropaleontol. 94-95, 72-79.

Spilling, K., 2007. Dense sub-ice bloom of dinoflagellates in the Baltic Sea, potentially limited by high pH. J. Plankton Res. 29, 895-901.

Stockmarr, J., 1972. Tablets withspores used in absolute pollen analysis. Pollen Spores 13, 615-621.

Stoecker, D.K., Buck, K.R., Putt, M., 1993. Changes in the sea-ice brine community during the spring-summer transition, McMurdo Sound, Antarctica. II. Phagotrophic protists. Mar. Ecol. Prog. Ser. 95, 103-113.

Stoecker, D.K., Gustafson, D.E., Baier, C.T., Black, M.M.D., 2000. Primary production in the upper sea ice. Aquat. Microb. Ecol. 21, 275-287.

Stoecker, D.K., Gustafson, D.E., Merrell, J.R., Black, M.M.D., Baier, C.T., 1997. Excystment and growth of chrysophytes and dinoflagellates at low temperatures and high salinities in Antarctic sea-ice. J. Phycol. 33, 585-595.

von Stosch, H.A., 1973. Observations on vegetative reproduction and sexual life cycles of two freshwater dinoflagellates, Gymnodinium pseudopalustre Schiller and Woloszynskia apiculata sp. nov. Br. Phycol. J. 8, 105-134.

Stroeve, J.C., Markus, T., Boisvert, L., Miller, J., Barrett, A., 2014. Changes in Arctic melt season and implications for sea ice loss. Geophys. Res. Lett. 41 (2013GL058951).

Stroeve, J., Serreze, M., Holland, M., Kay, J., Malanik, J., Barrett, A., 2012. The Arctic's rapidly shrinking sea ice cover: a research synthesis. Clim. Chang. 110, 1005-1027.

Susek, E., Zonneveld, K.A.F., Fischer, G., Versteegh, G.J.M., Willems, H., 2005. Organicwalled dinoflagellate cyst production in relation to upwelling intensity and lithogenic influx in the Cape Blanc region (off north-west Africa). Phycol. Res. 53, 97-112.
Taylor, F.J.R., 1987. General group characteristics, special features, short history of dinoflagellate study. In: Taylor, F.J.R. (Ed.), The Biology of Dinoflagellates. Blackwell Scientific Publications, Oxford.

Telford, R.J., Birks, H.J.B., 2011. Effect of uneven sampling along an environmental gradient on transfer-function performance. J. Paleolimnol. 46, 99-106.

Thomson, P., McMinn, A., Kiessling, I., Watson, M., Goldsworthy, P., 2006. Composition and succession of dinoflagellates and chrysophytes in the upper fast ice of Davis Station, East Antarctica. Polar Biol. 29, 337-345.

Tremblay, C., Runge, J.A., Legendre, L., 1989. Grazing and sedimentation of ice algae during and immediately after a bloom at the ice-water interface. Mar. Ecol. Prog. Ser. 56 291-300.

Turner, J.T., 2002. Zooplankton fecal pellets, marine snow and sinking phytoplankton blooms. Aquat. Microb. Ecol. 27, 57-102.

Uchida, T., 2001. The role of cell contact in the life cycle of some dinoflagellate species. J. Plankton Res. 23, 889-891.

Versteegh, G.J.M., Blokker, P., Bogus, K.A., Harding, I.C., Lewis, J., Oltmanns, S., Rochon, A. Zonneveld, K.A.F., 2012. Infra red spectroscopy, flash pyrolysis, thermally assisted hydrolysis and methylation (THM) in the presence of tetramethylammonium hydroxide (TMAH) of cultured and sediment-derived Lingulodinium polyedrum (Dinoflagellata) cyst walls. Org. Geochem. 43, 92-102.

Wall, D., Dale, B., 1966. "Living fossils" in western Atlantic plankton. Nature 211 $1025-1026$.

Walther, G.-R., Post, E., Convey, P., Menzel, A., Parmesan, C., Beebee, T.J.C., Fromentin, J.-M. Hoegh-Guldberg, O., Bairlein, F., 2002. Ecological responses to recent climate change. Nature 416, 389-395.

Wang, C., Granskog, M.A., Gerland, S., Hudson, S.R., Perovich, D.K., Nicolaus, M., Ivan Karlsen, T., Fossan, K., Bratrein, M., 2014. Autonomous observations of solar energy partitioning in first-year sea ice in the Arctic Basin. J. Geophys. Res. Oceans 119 2066-2080.

Warner, A.J., Hays, G.C., 1994. Sampling by the continuous plankton recorder survey. Prog. Oceanogr. 34, 237-256.

Warren, A., 2013. Ciliophora. Accessed through: World Register of Marine Species at http://www.marinespecies.org/aphia.php?p=taxdetails\&id $=11$.

Wassmann, P., Duarte, C.M., Agustí, S., Sejr, M.K., 2010. Footprints of climate change in the Arctic Marine Ecosystem. Glob. Chang. Biol. http://dx.doi.org/10.1111/j.1365-2486 2010.02311x (in press).

Zheng, S., Wang, G., Lin, S., 2012. Heat shock effects and population survival in the polar dinoflagellate Polarella glacialis. J. Exp. Mar. Biol. Ecol. 438, 100-108.

Zonneveld, K.A.F., 1997. New species of organic-walled dinoflagellate cysts from modern sediments of the Arabian Sea (Indian Ocean). Rev. Palaeobot. Palynol. 97, 319-337 (pl.1-4).

Zonneveld, K.A.F., Brummer, G.A., 2000. (Palaeo-)ecological significance, transport and preservation of organic-walled dinoflagellate cysts in the Somali Basin, NW Arabian Sea. Deep-Sea Res. II Top. Stud. Oceanogr. 47, 2229-2256.

Zonneveld, K.A.F., Marret, F., Versteegh, G.J.M., Bogus, K., Bonnet, S., Bouimetarhan, I., Crouch, E., de Vernal, A., Elshanawany, R., Edwards, L., Esper, O., Forke, S., Grøsfjeld, K., Henry, M., Holzwarth, U., Kielt, J.-F., Kim, S.-Y., Ladouceur, S., Ledu, D., Chen, L., Limoges, A., Londeix, L., Lu, S.H., Mahmoud, M.S., Marino, G., Matsouka, K. Matthiessen, J., Mildenhal, D.C., Mudie, P., Neil, H.L., Pospelova, V., Qi, Y., Radi, T., Richerol, T., Rochon, A., Sangiorgi, F., Solignac, S., Turon, J.-L., Verleye, T., Wang, Y., Wang, Z., Young, M., 2013. Atlas of modern dinoflagellate cyst distribution based on 2405 datapoints. Rev. Palaeobot. Palynol. 191, 1-198.

Zonneveld, K.A.F., Susek, E., Fischer, G., 2010a. Seasonal variability of the organic-walled dinoflagellate cyst production in the coastal upwelling region off Cape Blanc (Mauritania): a five-year survey. J. Phycol. 46, 202-215.

Zonneveld, K.A.F., Versteegh, G.J.M., de Lange, G.J., 1997. Preservation of organic-walled dinoflagellate cysts in different oxygen regimes: a 10,000 year natural experiment. Mar. Micropaleontol. 29, 393-405.

Zonneveld, K.A.F., Versteegh, G.J.M., Kasten, S., Eglinton, T.I., Emeis, K.C., Huguet, C., Koch, B.P., de Lange, G.J., de Leeuw, J.W., Middelburg, J.J., Mollenhauer, G., Prahl, F.G., Rethemeyer, J., Wakeham, S.G., 2010b. Selective preservation of organic matter in marine environments; processes and impact on the sedimentary record. Biogeosciences 7, 483-511. 